\title{
CUATRO DÉCADAS DE HISTORIOGRAFÍA DEL EVOLUCIONISMO EN ESPAÑ**
}

\author{
Jesús I. Catalá Gorgues
}

Universidad CEU Cardenal Herrera

\begin{abstract}
RESUMEN
La producción historiográfica sobre el evolucionismo en España ha dado lugar a un conjunto de trabajos originales muy apreciables, tanto en número como en calidad. Efectivamente, la difusión de las teorías evolucionistas ofrece materiales de estudio muy atractivos, bien desde el punto de vista de la historia de las ideas y de las teorías científicas, como desde la perspectiva de los estudios de la interacción social amplia que la ciencia establece con su entorno. Las profundas implicaciones ideológicas y religiosas que la cuestión evolucionista envuelve encuentran en el caso español un ejemplo especialmente interesante. Este artículo pretende ofrecer un panorama de las propuestas presentadas en los últimos cuarenta años, de modo que pueda servir como motivo de reflexión para nuevas líneas de investigación en el futuro.
\end{abstract}

PALABRAS CLAVE: Evolucionismo. Historiografía. Difusión. España. Siglos XIX y XX.

\section{FOUR DECADES OF HISTORIOGRAPHY ON EVOLUTIONISM IN SPAIN}

\section{ABSTRACT}

Historiographical production on evolutionism in Spain has given rise to a set of very appreciable original works both in number and quality. Indeed, the diffusion of evolutionist theories offers very attractive materials of study, as much from the point of view of the history of the ideas and the scientific theories, as from the approach around the studies of the broad social interaction that science establishes with its environment. The deep ideological and religious implications that the evolutionist question involves find in the Spanish case an especially interesting example. This paper tries to offer an overview about some proposals presented in the last forty years, so that it can give a cause for reflection for new research lines in the future.

KEY WORDS: Evolutionism. Historiography. Dissemination. Spain. -19 th and -20th century.

* Proyecto I+D (MEC) HUM 2006-04730/HIST, con financiación FEDER. 


\section{INTRODUCCIÓN}

La historia de las teorías evolucionistas, así como de los modos de difusión de las mismas, de su influencia en diferentes ámbitos de la ciencia o en la propia conformación de las ideologías, es uno de los más vivaces y productivos campos de indagación en la historia de la ciencia desde que hace medio siglo, los estudios sobre Darwin y su obra se reactivaran a raíz del centenario de la publicación del Origen de las especies. Es ya un lugar común hablar de la existencia de una «industria Darwin»; y aunque todavía se esté lejos de generar un volumen de obra semejante sobre otras cuestiones relacionadas con la historia del evolucionismo, se va camino de articular también una «industria Lamarck» y, en los últimos años, incluso una «artesanía Wallace», por poner ejemplos de autores a los que se dedican crecientes esfuerzos desde la historiografía.

España no ha permanecido al margen de este interés por todo lo que se relaciona con el conocimiento histórico de cuanto rodea a la concepción evolutiva de la vida. A día de hoy, y como pretendemos demostrar con este artículo, la producción española al respecto es copiosa, y su estándar es equiparable a la que se genera en países con mayor tradición e implantación institucional de la historia de la ciencia que el nuestro. Nuestro objetivo va a ser, más concretamente, ofrecer un panorama (nunca un estudio exhaustivo) de los estudios que, desde finales de los años sesenta, han ido nutriendo el cuerpo de conocimiento sobre el caso español en la cuestión evolucionista. Orillaremos deliberadamente aquellas contribuciones de autores españoles que no son relativas a tal caso nacional, no porque no existan o no sean de calidad ${ }^{1}$, sino por querer focalizar nuestra atención precisamente en los trabajos centrados en el modo en que la sociedad española se hizo eco - y en su caso, desarrolló unos discursos propios o peculiares - de la idea de la evolución de los seres vivos durante la época contemporánea. Nuestro acercamiento, por otro lado, será más analítico respecto a aquellas aportaciones respecto a las que media

1 A título de ejemplo reciente de cómo los historiadores españoles del evolucionismo rinden contribuciones de primer nivel sobre cuestiones no necesariamente centradas en su propio país, valga citar el libro del fallecido profesor Mariano Artigas, de la Universidad de Navarra, escrito en colaboración con Thomas Glick y Rafael Martínez, en el que, a partir de los Archivos Vaticanos, se estudian diversos casos de intervención de los organismos de control doctrinal de la Santa Sede para la valoración de la obra de evolucionistas católicos en el último cuarto del siglo XIX; v. ARTIGAS, M., GLICK, T.F., MARTínEZ, R.A. (2006), Negotiating Darwin. The Vatican confronts evolution 1877-1902, Baltimore, The Johns Hopkins University Press. 
una mayor distancia temporal, y más descriptivo en lo relativo a las más recientes. Y esto, porque el propio desarrollo del ámbito de estudio ya ha permitido probar en el banco del debate historiográfico las más antiguas, asunto que todavía está en marcha para las más próximas en el tiempo.

Para situar estas cuatro décadas de estudios de historia del evolucionismo en España, hay que tener en cuenta la peculiar circunstancia vivida tras la Guerra Civil, con una fractura evidente en la continuidad de la propia actividad de los científicos evolucionistas españoles, en su mayoría en el exilio. La reactivación de la presencia pública de la evolución llevó un tiempo; y aunque en los años cuarenta se puedan encontrar algunas publicaciones, lo cierto es que se estaba muy lejos de una normalización. En cualquier caso, habrá que esperar a la segunda mitad de los años cincuenta y a la década de los sesenta para encontrar un período lo bastante efervescente en cuanto a la publicación de obras sobre evolucionismo como para que la recuperación del terreno perdido empezara a columbrarse. La actividad de paleontólogos como Miquel Crusafont y Bermudo Meléndez, de ecólogos como Ramón Margalef o de bioquímicos como Faustino Cordón, contribuyó por entonces a que la investigación, la divulgación y la docencia sobre la evolución fueran ocupando un espacio, todavía pequeño pero creciente, en el panorama científico español de la época ${ }^{2}$. El estímulo de la conmemoración del centenario del Origen de las especies en 1959, y en menor medida, el de la contribución conjunta de Darwin y Wallace a la teoría de la selección natural el año anterior, permitieron extender el interés e, incluso, motivar la aparición de algunas publicaciones, como el grueso volumen monográfico sobre evolucionismo de la Revista de la Universidad de Madrid ${ }^{3}$, en el que participaron no sólo autores españoles como los tres primeros mencionados, sino también extranjeros de la talla de Theodosius Dobzhansky ${ }^{4}$ y Pierre-Paul Grassé5. De todos modos, España, un país tradicionalmente católico que por entonces estaba bajo un régimen político que había encontrado en la Iglesia un soporte impor-

2 Aunque incompleta, continúa siendo muy útil para hacerse una idea de la situación de los estudios evolucionistas en España en los años cincuenta y sesenta BIBLIOGRAFÍA (1982), Bibliografía hispánica sobre Darwin y el darwinismo, Anthropos, 16-17, pp. 15-54.

3 VV.AA. (1959), La teoría de la evolución a los cien años de la obra de Darwin, Revista de la Universidad de Madrid, 8 (29-31).

4 Dobzhansky, T. (1959), Evolución y genética. Revista de la Universidad de Madrid, 8 (29-31), pp. 165-186. Se trataba de un texto preparado a partir de varios artículos, ensamblados y traducidos por Rafael Alvarado con el permiso de Dobzhansky.

5 GRASSÉ, P.P. (1959), Les incertitudes des doctrines evolutionnistes, Revista de la Universidad de Madrid, 8 (29-31), pp. 275-294. 
tante en lo ideológico y en lo social, hallaría una vía particular de consolidación de los estudios evolucionistas precisamente a través de su vinculación a los círculos de pensamiento y reflexión católicos. Ya en 1954 se había celebrado en Salamanca, con ocasión del séptimo centenario de la Universidad, un Congreso de Ciencias eclesiásticas en cuya sección de Filosofía y Teología se trató monográficamente el evolucionismo, con la intervención de diversos autores, la mayoría miembros de congregaciones religiosas; en la presentación del libro colectivo que generó dicha sección, se reconoce explícitamente el papel impulsor que tuvo la encíclica Humani generis, promulgada por el papa Pío XII en 1950, en la convocatoria del encuentro ${ }^{6}$. En cualquier caso, nos atrevemos a postular tentativamente, a falta de una investigación histórica específica, que la difusión de la obra del paleontólogo jesuita francés Pierre Teilhard de Chardin tras su fallecimiento en 1955, de la mano especialmente de Crusafont - científico de profundas convicciones católicas, como es bien sabido 7 - fue un estímulo clave en la toma de conciencia entre los autores católicos acerca del evolucionismo, especialmente en el ambiente de reforma eclesial que el Concilio Vaticano II contribuyó a conformar en los sesenta. Ya el mencionado volumen de la Revista de la Universidad de Madrid contenía un artículo sobre la evolución y las doctrinas católicas, en el que se hacía una revisión de las ideas teilhardianas ${ }^{8}$, y algo antes, la revista de la Archidiócesis de Santiago, Compostellanum, había publicado un artículo específico sobre estas últimas ${ }^{9}$. El hecho más significativo, en todo caso, fue la aparición en 1966 del volumen colectivo La evolución - editado por La Editorial Católica en su celebérrima Biblioteca de Autores Cristianos- bajo la dirección del propio Crusafont - ya entonces catedrático de paleontología de la Universidad de Barcelona-, de Meléndez — que ocupaba idéntico puesto en Madrid-, y del también paleontólogo Emiliano Aguirre, profesor así mismo en la Universidad de Madrid y jefe de laboratorio en el CSIC, además de miem-

6 VV.AA. (1956), El evolucionismo en filosofía y teología, Barcelona, Juan Flors, p. VII.

7 MaÑosa, M. (1995), Miquel Crusafont i Pairó. Sabadell, 1910-1983. L'escola paleontològica de Sabadell. En CAmarasa, J.M., Roca Rosell, A. (dirs.), Ciència i Tècnica als Països Catalans: una aproximació biogràfica, Barcelona, Fundació Catalana per a la Recerca, pp. 1443-1472.

8 Benzo, M. (1959), Evolución y dogma, Revista de la Universidad de Madrid, 8 (2931), pp. 533-559, especialmente pp. 551-559. También se citaba a Teilhard en AGUIRRE, E. (1959), Aspectos filosóficos y teológicos de la evolución, Revista de la Universidad de Madrid, 8 (29-31), pp. 445-531.

9 Guerra, J. (1957), El evolucionismo de Teilhard de Chardin, Compostellanum, 2, pp. 501-520. 
bro, por entonces, de la Compañía de Jesús ${ }^{10}$. Contaron los directores con la colaboración de algunos destacados especialistas españoles de la época, como el ya mencionado Margalef o el bioquímico Vicente Villar Palasí, que ya habían contribuido al volumen de la Revista de la Universidad de Madrid, así como el genetista Antonio Prevosti, el paleontólogo Jaume Truyols, los zoólogos Rafael Alvarado, Francisco Bernis y José Antonio Valverde, el citólogo Salustio Alvarado, el filósofo Carlos París, el endocrinólogo Juan Rof Carballo, y otros más, incluyendo a unos cuantos religiosos, como los jesuitas Luis M. ${ }^{a}$ Armendáriz - profesor de teología dogmática, que abordó uno de los grandes asuntos de la obra, la fe cristiana y la evolución- y Eusebio Colomer - que centró su contribución en Teilhard de Chardin, precisamente-, y el franciscano Luis Arnaldich, escriturista ${ }^{11}$. El volumen, a la postre, culminaba el proceso de prudente y progresiva expansión de los estudios sobre evolución en España, a partir de la difícil situación de partida que el final de la Guerra Civil había configurado. Representaba, también, sellar formalmente las viejas disputas en torno a la evolución que varias generaciones de polemistas católicos habían mantenido vivas desde los tiempos de la primera difusión de las obras de Darwin en España.

El interés por la historia del evolucionismo fue ganando terreno paralelamente. La citada obra colectiva de 1966 incluía, de hecho, un capítulo sobre la cuestión, redactado por el entomólogo e histólogo Joaquín Templado, a quien se debían ya varias reflexiones históricas sobre la obra de Darwin, de Wallace o sobre el evolucionismo en sentido amplio ${ }^{12}$. La atención a la histo-

10 Todo un símbolo: los jesuitas españoles, a principios de siglo entre los más firmes impugnadores del darwinismo y otras corrientes evolucionistas (recordemos a Pujiula o Ibero), tenían ahora un miembro que codirigía una obra que partía de la absoluta compatibilidad entre fe católica y evolución. El propio Aguirre ya había publicado años antes un estudio donde rastreaba indicios de evolucionismo en la obra de José de Acosta; v. AguirRe, E. (1957), Una hipótesis evolucionista en el siglo XVI. El P. José de Acosta, S.I, Arbor, 134, pp. 175-187.

11 Crusafont, M., MelÉndez, B., Aguirre, E. (dir.), La Evolución, Madrid, La Editorial Católica (Biblioteca de Autores Cristianos).

12 Templado, J. (1958), En el centenario de Darwin y Wallace, Arbor, 156, pp. 398-404; TEMPlado, J. (1959a), Darwin y el darwinismo, Arbor, 165-166, pp. 628-633; TEMPlado, J. (1959b), Un siglo de evolucionismo, Revista de la Universidad de Madrid, 8 (29-31), pp. 1747; Templado, J. (1963), Alfred R. Wallace (1823-1913) y la teoría de la evolución, Arbor, 215, pp. 89-97; TEMPLADO, J. (1965), Genética, evolución y comunismo: el caso Lysenko, Arbor, 240, pp. 61-66; TeMPLADO, J. (1969), Las ideas evolucionistas de Lamarck, Arbor, 283-284, pp. 41-53. Este autor acabó publicando un panorama histórico del evolucionismo en el que incorporó algunas pinceladas sobre la recepción en España; v. TEMPLADO, J. (1974), Historia de las teorías evolucionistas, Madrid, Alhambra, pp. 98-99. El volumen también 
ria del evolucionismo español estaba, en todo caso, sólo en sus primeros balbuceos. Aunque, lógicamente, aparecían referencias a la cuestión en obras de alcance más general ${ }^{13}$, y algunos artículos habían explorado la visión del evolucionismo en aspectos concretos, como la apologética española de finales del siglo XIX ${ }^{14}$, la obra de Emilia Pardo Bazán ${ }^{15}$, la traducción de la obra de Darwin ${ }^{16}$ o el pensamiento de Miguel de Unamuno ${ }^{17}$, todavía no estaba abierto ningún programa de investigación específico y de alcance sobre el modo en que las teorías evolucionistas habían sido recibidas, discutidas y aplicadas en España.

\section{LOS INICIOS DE UNA HISTORIOGRAFÍA ESPECÍFICA SOBRE EL EVOLUCIONISMO EN ESPAÑA}

Fue Thomas F. Glick, un joven profesor estadounidense de la Universidad de Texas, doctorado poco antes en Historia en Harvard, quien inició en 1969 lo que podemos considerar la primera línea de trabajo perseverante y bajo un prisma historiográfico actualizado sobre la recepción del darwinismo en España. Glick, bien formado como arabista a partir de sus estudios en Barcelona con Millás y Vernet, había llevado hasta entonces su carrera científica por el

incluía referencias a «precursores» como Acosta o Félix de Azara; v. TEMPLAdo (1974), pp. $11-13$ y $43-48$.

13 Por ejemplo, LóPez Piñero, J.M., García Ballester, L., Faus, P. (1964), Medicina y sociedad en la España del siglo XIX, Madrid, Sociedad de Estudios y Publicaciones, pp. 94 y ss. muy especialmente.

14 SANUS, R. (1962), Algunos aspectos de la apologética española en la segunda mitad del siglo XIX, Almena, 2, pp. 11-32. En este trabajo, el autor se ocupaba principalmente de la obra del teólogo dominico Juan T. González de Arintero, sobre el que hay una amplia bibliografía; exploran cuestiones relacionadas con el evolucionismo HUERGA, A. (1967), La «evolución»: clave y riesgo de la aventura intelectual arinteriana, Studium, 7, pp. 127-153, y diversas colaboraciones en el monográfico VV.AA. (1978), Juan G. Arintero, O.P. Evolucionista, apologeta, eclesiólogo y reorientador de la espiritualidad cristiana, Teología espiritual, 22 (65-66).

15 KYRBY, H.L. (1964), Pardo Bazán, Darwinism and La madre naturaleza. Hispania, 47, pp. 733-737.

16 ZabalbeascoA, J.A. (1968), El primer traductor de Charles R. Darwin en España, Filología moderna, 31-32, pp. 269-275.

17 EARLe, P.G. (1964), El evolucionismo en el pensamiento de Unamuno, Cuadernos de la Cátedra Miguel de Unamuno, 14-15, pp. 19-28. La cuestión sobre Unamuno y el evolucionismo es tratada también por Carlos París en diferentes obras; v. PARís, C. (1968), Unamuno: estructura de su mundo intelectual, Barcelona, Península, y PARÍs, C. (1965), Unamuno y Teilhard de Chardin, Cuadernos para el Diálogo, 16, pp. 13-14. 
ámbito de la historia de las técnicas de riego, con una tesis doctoral centrada en los regadíos de la Valencia medieval. Aquí, ya mostró interés por la relación de la difusión del conocimiento con los cambios culturales y sociales. Por ello, y a pesar del cambio radical de época y contexto que suponía pasar de la Edad Media al siglo XIX, asumió sin embargo esa nueva línea de trabajo, cuyos resultados lo acabaron convirtiendo en referencia necesaria de la historiografía española y mundial sobre evolucionismo ${ }^{18}$.

En el mencionado año, Glick presentó ante el III Congreso Nacional de Historia de la Medicina, celebrado en Valencia entre el 10 y el 12 de abril, sendas comunicaciones dedicadas a la recepción del darwinismo en España ${ }^{19}$, y al homenaje a Darwin en Valencia con motivo del centenario de su nacimiento ${ }^{20}$. La primera constituye una propuesta programática, en la que el autor declaraba «presentar unos esquemas para el estudio comparativo de la recepción del darwinismo en España y en Hispanoamérica, un estudio que, en verdad, no he empezado todavía» ${ }^{21}$. Glick proponía, a título provisional, un esquema cronológico del darwinismo en España en cuatro etapas, que con matices, ha venido siendo explícita o implícitamente aceptado por casi todos los historiadores que se han ocupado del tema, a pesar de las pequeñas inadecuaciones que se han ido revelando:

- 1. a etapa (1859-1868), a la que Glick llama «Los albores del darwinismo en España», caracterizada por una difusión muy lenta de las ideas de Darwin y una discusión muy limitada a círculos académicos. La escasez de fuentes en este período, que Glick toma como señal de una penetración muy superfi-

18 Martínez Sanmartín, L.P. (2003), Glick, Thomas F. En Simon i TARrés, A. (dir.), Diccionari d'historiografia catalana, Barcelona, Enciclopedia Catalana, pp. 531-532; RocA RoSELL, A. (2004), Elogio de Thomas F. Glick. Premio Internacional Geocrítica 2004, Scripta Nova. Revista Electrónica de Geografia y Ciencias Sociales, 8 (170), 77 [http://www.ub.es/geocrit/sn/sn-17077.htm (17-8-2009)].

19 GLICK, T.F. (1969), La recepción del darwinismo en España en dimensión comparativa, Asclepio, 21, pp. 207-214. En este volumen de Asclepio se publicaron parte de las comunicaciones presentadas al Congreso, en concreto, las que se ocupaban de la medicina en la España del siglo XIX. Posteriormente, fueron publicadas de nuevo en las propias actas del Congreso; la que nos ocupa apareció reimpresa en III Congreso Nacional de Historia de la Medicina. Actas, vol. I, Madrid/Valencia, Sociedad Española de Historia de la Medicina, pp. 193-200, (1971).

20 GLICK, T.F. (1971), The Valencian Homage to Darwin in the Centennial Date of his Birth. En III Congreso Nacional de Historia de la Medicina. Actas, vol. II, Madrid/Valencia, Sociedad Española de Historia de la Medicina, pp. 577-601.

21 GLICK (1969), p. 207. 
cial $^{22}$, se ha revelado después como un problema de primer orden a la hora de comprender cabalmente la llegada de las ideas de Darwin a nuestro país.

- 2. ${ }^{a}$ etapa (1868-1880), caracterizada por un «darwinismo militante» y la consiguiente «reacción furibunda». Distingue dos fases. La primera, hasta 1872 , viene marcada porque los profesores empiezan a enseñar evolución abiertamente en las cátedras universitarias y, en su final, por las reacciones a El origen del hombre. La segunda, desde 1873, «quizás se caracterice por su contenido polémico». Destaca en ella la cuestión universitaria de 1875 y la expulsión de las cátedras de varios darwinistas. Su importancia estriba en que se fijaron las líneas de las futuras batallas, una vez que la orientación liberal y librepensadora de la mayoría de los darwinistas quedó asegurada ${ }^{23}$. Sin duda, este período ha sido el que más atención ha suscitado posteriormente; el propio Glick, como veremos, le dedicará un esfuerzo importante, como también otros autores atraídos por la historiografía de los conflictos.

- 3. a etapa (1880-1936), la de "consolidación del evolucionismo en la comunidad científica y [...] entre los intelectuales liberales». Se trata de un período en que disminuyeron progresivamente las polémicas, de modo que el darwinismo se hizo normal en los círculos científicos españoles, aunque aún quedara al margen de la sociedad dirigente y ortodoxa ${ }^{24}$. A la vista de estudios posteriores, ésta es, posiblemente, la fase peor caracterizada. Aunque es cierto que el tono extremista de las disputas fue disminuyendo, éstas no dejaron de presentarse; pero, sobre todo, no se normalizó la asunción de las doctrinas de Darwin, sino que diversas versiones de evolucionismo penetraron en el discurso - y sólo eventualmente en la práctica - de diversos científicos españoles, a quienes también afectó en este período el llamado «eclipse del darwinismo».

- 4. ${ }^{\mathrm{a}}$ etapa (1939-1969), en la que, tras la interrupción de la Guerra Civil, desaparecieron por muerte o exilio los seguidores del darwinismo y se empezó a desarrollar «una nueva escuela dentro de la iglesia» que asumía las teorías del jesuita francés evolucionista Pierre Teilhard de Chardin; su acción tuvo el efecto positivo de quitar carga polémica al evolucionismo y propiciar su difusión y aceptación, aunque paradójicamente fuera una escuela al margen de la ortodoxia científica surgida tras la Nueva Síntesis. Estos teilhardistas son caracterizados por Glick, tomando los esquemas de López Piñero, como una verdadera «generación intermedia» que salva el hueco entre la generación

\footnotetext{
22 GLICK (1969), p. 207.

23 GLICK (1969), pp. 207-208.

24 GLICK (1969), p. 208.
} 
de los 20 y 30, perdida para España por el conflicto bélico, y la nueva generación, ortodoxa científicamente, que se estaba conformando precisamente a finales del los años $60^{25}$. Esta fase continúa siendo la menos estudiada por los historiadores españoles, a pesar de que ahora contemos con una distancia temporal mucho mayor que la que podía tener Glick en el momento de presentar su propuesta. Por otro lado, y asumiendo a grandes rasgos la funcionalidad de su actuación, sólo de forma matizada podríamos admitir la inserción categórica de los teilhardistas dentro de la Iglesia en razón de su propio sentimiento eclesial, no porque hallaran, en modo alguno, una acogida entusiasta generalizada a sus propuestas, ni en España ni en el conjunto del orbe católico.

En este mismo trabajo, Glick entra también a considerar los factores que influyen en la recepción del darwinismo. En este punto, reivindica los estudios comparados para la valoración de la recepción del darwinismo en los diferentes países de occidente, hasta entonces apenas considerados, a pesar de que ya el propio Darwin se había dado cuenta de cómo sus ideas eran mejor o peor recibidas en según qué país, con el ejemplo evidente de Alemania y Francia. Según Glick, esa perspectiva comparada permitiría explicar mucho mejor los diferentes ritmos de recepción y el papel de las escuelas científicas nacionales, del Estado y de las iglesias ${ }^{26}$. Su obra posterior, como veremos, tomará muy en serio su propia reivindicación.

Son tres los grupos de factores que aprecia Glick que deben ser analizados. En primer lugar, la posición de los científicos en el país receptor, que permite explicar rasgos comunes, como que los científicos generalistas tendieron a recibir con más entusiasmo el darwinismo frente a los especializados (no en vano, Darwin ensaya una explicación general de los fenómenos de la vida), y también rasgos particulares, como el hecho de que en España los primeros defensores destacados fueran médicos. Una explicación de esto, admite Glick, podría residir en que las ideas evolucionistas estaban presentes en las obras de anatomía usadas en las facultades españolas, como la de Leon Testut, seguidor francés de Carl Gegenbaur; sin embargo Glick juzgaba más importante el tipo de enseñanza médica en la España de la época, que daba mucha importancia a los fundamentos científicos generales ${ }^{27}$. En cuanto a la indiferencia de los científicos de laboratorio, Glick ponía un ejemplo no demasiado afortunado, el de Santiago Ramón y Cajal, de quien sabemos de su interés por la cuestión evolucionista en los inicios de su carrera científica, activado espe-

25 GLICK (1969), pp. 208-209.

26 GLICK (1969), p. 210.

27 GLICK (1969), p. 211. 
cialmente durante sus años en Valencia, y de sus posteriores reflexiones críticas al respecto ${ }^{28}$. A la postre, era una actitud más o menos receptiva a la explicaciones generales sobre la vida lo que marcaba la recepción del darwinismo en cada país. Glick, en consecuencia, concluye que «la orientación de las escuelas científicas nacionales es el factor más importante para la recepción de las ideas darwinistas» ${ }^{29}$.

Al segundo grupo de factores - intelectuales, políticos y religiosos-, que engloba bajo el genérico epígrafe de «clima de la recepción», otorga Glick un papel importante pero subordinado. Lo que será un crítica posterior recurrente de Glick a la asociación estrecha entre recepción del positivismo y recepción del darwinismo empieza a asentarse en este trabajo. Según Glick, la versión spenceriana del positivismo es favorable al darwinismo, mientras que los comtianos son hostiles o indiferentes. Por eso, aunque positivismo y darwinismo sean núcleos de las fuerzas antirreligiosas en muchos países, no fueron de la mano en Francia y sí en la mayoría de países hispanoamericanos, donde dominaban las ideas spencerianas. En cuanto a la oposición religiosa, Glick la considera un factor destacado pero que frecuentemente se valora de forma exagerada. En los países católicos, la oposición de la Iglesia fue constante, pero la mayor o menor agresividad no parece influir en el éxito o el fracaso de las ideas darwinistas. El grado en que cada Iglesia en cada país se oponía, dependía de la actitud de las escuelas científicas nacionales, y no al revés. Por eso en Francia muchos autores católicos consideraban a Darwin en un plano estrictamente científico, mientras que en España se fue mucho más allá. Por último, por lo que respecta a la acción del poder político, podía influir sobre todo si apoyaba oficialmente a la religión mayoritaria. El Estado español fue más eficaz, por ello, que el francés, aunque ambos presionaron a través de la censura y el control de cátedras e instituciones. A la postre, fueron medidas que afectaron a personas concretas, pero fueron poco efectivas para detener el curso de las ideas. A lo sumo, se logró retrasar políticamente la introducción del darwinismo, como mostraba el caso español (hasta la revolución), pero también el estadounidense (hasta el final de la Guerra de Secesión) o el mexicano (hasta la reforma de la enseñanza por Juárez en 1867) ${ }^{30}$.

Finalmente, el tercer grupo de factores son aquellos relacionados con el propio acto de difusión y recepción de las ideas. No es lo mismo recibir el darwinismo en la versión original de las obras del autor, que en las traducciones o en los comentarios. En el caso español, era evidentemente significativo que

28 LÓPez Piñero, J.M. (2000), Cajal, Madrid, Debate, pp. 87 y 188.

29 GLICK (1969), p. 212.

30 GLICK (1969), pp. 212-213. 
se tradujera antes El origen del hombre que El origen de las especies, y simultáneamente se pusieron en circulación traducciones de diversas obras de Haeckel, lo que explicaría que éste acabara siendo tan influyente como Darwin ${ }^{31}$.

Más allá del esquema cronológico propuesto, o de la caracterización de niveles de análisis aportada, este primer trabajo de Glick sobre el evolucionismo en España puede juzgarse especialmente influyente por la asunción de un enfoque inequívocamente difusionista que, implícita o explícitamente, será a su vez adoptado por autores posteriores. La consideración periférica de España en el contexto de la ciencia europea de la época había pasado a ser un lugar común, y una aproximación en clave de difusión desde un centro productivo de conocimiento - planteamiento teórico-metodológico en boga en aquella época - era, para el caso del evolucionismo, de aplicación sencilla ${ }^{32}$.

La segunda comunicación que presentó Glick al III Congreso Nacional de Historia de la Medicina se ocupaba de un episodio concreto en la recepción del darwinismo en España: el homenaje tributado a Darwin en la Universidad de Valencia en 1909, con motivo del centenario de su nacimiento. En este trabajo, Glick fijaba las coordenadas básicas de tal proceso de recepción en la ciudad del Turia, con especial énfasis en el papel del catedrático de la Facultad de Medicina Peregrín Casanova ${ }^{33}$. Más allá de los hechos que son motivo central del trabajo - la organización del homenaje, su desarrollo en una velada y la instalación de una lápida conmemorativa ${ }^{34}$-, frecuentemente glosados o repetidos en otras publicaciones del propio Glick o de otros autores, destaca en esta aportación el uso extenso de la prensa de información general para pulsar las respuestas de los diferentes sectores ideológicos, representados en unas u otras cabeceras ${ }^{35}$. El recurso a las fuentes hemerográficas será, ciertamente, un rasgo característico de los estudios de Glick sobre la recepción de las nuevas ideas científicas, como ponen de manifiesto sus aportaciones sobre la recepción del psicoanálisis ${ }^{36}$ y sobre la

31 GLick (1969), pp. 213-214.

32 Muchos años después, el propio Glick plantearía algunas posibilidades de crítica al modelo centro-periferia; v. GLICK, T.F. (1993), Les dimensions comparatives en la història de les ciències. En Navarro, V., Salavert, V.L., Corell, M.V., Moreno, E., Rosselló, V. (coords.), Actes de les II Trobades d'Història de la Ciència i de la Tècnica, Barcelona, Societat Catalana d'Història de la Ciència i de la Tècnica, pp. 59-70.

33 GLICK (1971), pp. 577-583.

34 GLICK (1971), pp. 583-596.

35 GLICK (1971), pp. 596-601, especialmente.

36 GLICK, T.F. (1988), El impacto del psicoanálisis en la psiquiatría española de entreguerras. En SÁnchez Ron, J.M. (ed.), Ciencia y sociedad en España: de la Ilustración a la Guerra Civil, Madrid, CSIC/El Arquero, pp. 205-221. 
difusión de la teoría de la relatividad en España ${ }^{37}$.

Al año siguiente del Congreso de Valencia, Glick aportó un nuevo trabajo sobre la recepción del darwinismo en España. Se trata de un breve capítulo en el libro sobre la Revolución de 1868 que dirigieron la historiadora social argentina Clara Eugenia Lida y la historiadora de la literatura, de origen puertorriqueño, Iris M. Zavala ${ }^{38}$. En esta aportación, Glick conectaba las polémicas tempranas con «the struggle of liberal Spaniards to implant a secular base for education and science and that of conservative, orthodox Spaniards to oppose such a restructuring of traditional institutions», que podría caracterizar, según el autor, la historia de la ciencia en España desde el siglo XVIII ${ }^{39}$. El recurso a una retórica del conflicto, que evoca en un caso como el descrito la caracterización de la relación entre ciencia y religión en términos bélicos, no deja de ser llamativa. El valor de esta pequeña contribución de Glick hay que buscarlo en su inserción en un volumen colectivo sobre un aspecto crucial de la historia española contemporánea, publicado en el extranjero y que contó con la participación de destacados especialistas; pero sobre todo, en el hecho de que, al lado de la historia política y económica, de los movimientos sociales o de la Iglesia, la historia de la ciencia y de las ideas quedaba perfectamente integrada a la aproximación cultural a la Revolución de 1868 .

Una aportación mucho más sustancial del historiador norteamericano llegó con la conferencia sobre la recepción comparada del darwinismo que él mismo organizó en Austin (Texas) y que tuvo lugar el 22 y 23 de abril de 1972. Allí se expusieron en clave comparativa los casos británico, alemán, francés, estadounidense, ruso, holandés, español y mexicano, más una contribución desde la perspectiva islámica y reflexiones generales sobre la historiografía del darwinismo y sobre la relación entre darwinismo y religión. Como el propio Glick recordaba en el prefacio al volumen que recogió las diferentes contribuciones, la idea lanzada en Valencia se materializaba ahora en una reunión científica internacional ${ }^{40}$, sa-

37 GLICK, T.F. (2005), Einstein y los españoles: ciencia y sociedad en la España de entreguerras, Madrid, CSIC, pp. 11-12. En el prólogo de este libro menciona lo que llama «el método de los diarios».

38 GLICK, T.F. (1970), Science and the Revolution of 1868: Notes on the Reception of Darwinism in Spain. En LidA, C.E., Zavala, I.M. (ed.), La Revolución de 1868: Historia, pensamiento, literatura, Nueva York, Las Américas, pp. 267-272.

39 GLick (1970), p. 267.

40 Glick, T.F. (1974a), Preface. En Glick, T.F. (ed.), The Comparative Reception of Darwinism, Austin/Londres, University of Texas Press, pp. VII-IX. En el momento de la publicación del libro, Glick ya había pasado a formar parte del claustro de la Universidad de Boston, donde ha proseguido el resto de su carrera científica y académica. 
ludada efusivamente como "an important step toward incorporating comparative studies on the reception of Darwinism in various countries $\rangle^{41}$, y cuyos resultados ya son clásicos de la historiografía mundial sobre el evolucionismo. Glick presentó, naturalmente, un trabajo sobre el caso español ${ }^{42}$, centrándose en el período comprendido entre 1868 y el fin de siglo, de modo que diluía la separación entre la segunda y la tercera etapas propuestas en su comunicación de 1969, aunque mantuviera la caracterización de rasgos, en cuanto a la intensa reacción católica antidarwinista de los primeros años de la Restauración y su posterior apaciguamiento. Aquello que postulaba ahora, de forma menos rígida, era un triple análisis de los procesos de polarización, normalización y popularización del darwinismo en España, que quedarían sustancialmente completados en 1909, con el homenaje en Valencia como símbolo ${ }^{43}$.

Glick reconocía que para estudiar el proceso de normalización —entendiendo como tal, la progresiva pérdida de carácter polémico del darwinismo entre los científicos - se necesitaba más documentación. Por ello, centró su análisis en la polarización. Se trata de la primera exposición de conjunto sobre el tema, en la que salen a relucir algunos de los asuntos esenciales que caracterizaron el proceso: la apertura ocasionada por la proclamación de la libertad de cátedra al poco del triunfo revolucionario; las restricciones tras la crisis universitaria de 1875 , a la postre sin éxito completo por el grado de penetración que ya había alcanzado el darwinismo; la consideración referencial que tuvo la versión haeckeliana del darwinismo en la difusión de éste en España, con personajes como Casanova y diversos médicos y naturalistas de tendencia positivista como principales adherentes; la extensión del pensamiento evolucionista a las ciencias sociales; la diseminación del darwinismo, más allá de la intelectualidad madrileña, por otros muchos lugares del país, como Sevilla, Valencia o las Islas Canarias, etc., y más allá de la universidad, al ámbito de la enseñanza media. También, la complejidad de la respuesta católica, que pasó del rechazo frontal a los intentos de acomodar la evolución a una perspectiva creyente. La principal conclusión de Glick es demoledora: «Looking back on the Darwin

41 GReENE, J.C. (1975), Reflections on the Progress of Darwin Studies, Journal of the History of Biology, 8, pp. 243-273, p. 249. También hubo, no obstante, valoraciones más críticas, como las que son citadas en RESTREPO, O. (2002), Leyendo historias sobre el darwinismo. En Puig-Samper, M.A., Ruiz, R., Galera, A. (ed.), Evolucionismo y Cultura. Darwinismo en Europa e Iberoamérica, Madrid, Junta de Extremadura/UNAM/Doce Calles, pp. 21-45.

42 Glick, T.F. (1974b), Spain. En Glick, T.F. (ed.), The Comparative Reception of Darwinism, Austin/Londres, University of Texas Press, pp. 307-345.

43 GLICK (1974b), p. 344. 
polemic in nineteenth-century Spain one must admit, first, the utter banality of the debate» ${ }^{44}$. La escasez de ideas originales por parte de los defensores del darwinismo, junto con las posturas inanes de los detractores, todo ello con ribetes de patetismo rayando en lo ridículo, caracterizaron en general los debates. Glick sólo salvaba de la carencia de nivel científico a los neurohistólogos, ejemplificados en las figuras de Luis Simarro y de Santiago Ramón y Cajal, rehabilitado ahora como darwinista en contra de lo que, como hemos visto, había expresado el propio autor tres años antes. En cualquier caso, y más allá del juicio negativo sobre la altura intelectual del debate en España, Glick destacaba el vigor con el que se manifestó, en buena medida porque la militancia en un bando u otro suponía un compromiso público fuerte; para los evolucionistas, porque les llevaba a estar en el filo de la navaja, de modo que proyectaban una imagen intrépida de adalides de las nuevas ideas; para los antievolucionistas, porque se presentaban como los salvadores del país ante la influencia perniciosa de las ideas extranjeras, especialmente de aquéllas que venían de Alemania ${ }^{45}$. Mucho más maduro, este trabajo de Glick matizaba la conclusión que, a modo de hipótesis de trabajo, sostuviera en su comunicación de 196946; no obstante, y a pesar del peso indudable que lo ideológico tenía en el proceso de polarización ante el darwinismo ${ }^{47}$, insistía en el componente social de la cuestión, presentando las nuevas ideas en su ligazón a una clase media que estaba surgiendo como grupo a la vez que espabilaba intelectualmente, en un proceso secularizador que plantaba cara al poder de la tradición eclesiástica ${ }^{48}$.

El énfasis social de Glick, marcado por el influjo de la antropología de la difusión cultural de la que era deudor ${ }^{49}$, tuvo un cierto contrapunto en la otra gran contribución de los años setenta sobre la recepción de las ideas evolucionistas en nuestro país. En 1977 vio la luz El darwinismo en España, una colección de textos en torno a la polémica, recopilados por Diego Núñez, de

44 GLICK (1974b), p. 343.

45 GLICK (1974b), pp. 343-344.

46 «He intentado trazar algunas áreas de investigación del estudio de la recepción del darwinismo, sobre todo en los países católicos. Las ideas raras veces atraviesan las fronteras sin sufrir modificaciones, sino que resultan afectadas por factores de selectividad. En resumen, parece que los factores decisivos no son tanto los políticos o religiosos, sino los dependientes de la educación, de la mentalidad y de los intereses de los científicos del país» (GLICK (1969), p. 214).

47 Glick ha hecho explícita en alguna ocasión su vocación por la historia de las ideas; v. al respecto GLICK, T.F. (1985), Crítica a N. Stepan y L. Pyenson, Quipu, 2 (3), pp. 437-442.

48 GLICK (1974b), p. 345.

49 GLICK (1985), p. 437. 
la Universidad Autónoma de Madrid, autor además del extenso estudio preliminar en el que situaba la cuestión en el contexto peculiar de la España decimonónica ${ }^{50}$. La selección de fuentes estaba marcada por el interés de Núñez en el estudio de las connotaciones ideológicas y filosóficas del darwinismo mucho más que en el estudio de su recepción desde el punto de vista científico; tal enfoque era coherente con su propia trayectoria de investigador, que había dado lugar cuatro años antes a su tesis doctoral, dirigida por Carlos París, sobre la mentalidad positiva en España, publicada como libro en $1975^{51}$, y que incluía un capítulo sobre «La presencia del evolucionismo en el pensamiento español decimonónico»; en él, Núñez realizaba un rápido repaso de algunas de las primeras contribuciones de autores españoles al debate evolucionista durante el último tercio del siglo XIX, más una breve valoración del influjo del evolucionismo de raíz spenceriana en nuestro país, y un análisis, algo más extenso, de lo que ha acabado siendo leitmotiv de los estudios de historia del evolucionismo en España: la difusión de las ideas evolucionistas de diversos autores alemanes materialistas, y muy especialmente de la propuesta monista de Haeckel, tanto entre naturalistas y filósofos, como entre médicos y activistas políticos ${ }^{52}$.

Esta primera aportación de Núñez puede ser considerada, básicamente, un planteamiento descriptivo de partida, sin ir mucho más allá de la localización de autores y tendencias, aunque con el valor añadido de aportar fuentes tempranas, correspondientes a los años anteriores a 1868. Mucho más analítico resultó ya el mencionado estudio introductorio de El darwinismo en España, en el que argumentaba por extenso sobre el vínculo del evolucionismo darwinista en su proceso de difusión en España con la propia dinámica de extensión del positivismo. Núñez adoptó tres niveles de análisis, los cuales correspondían básicamente a tres concepciones del mundo:

— La oposición al darwinismo por los sectores tradicionales, a partir de argumentos básicamente morales y religiosos.

50 NúÑEZ, D. (1977), El darwinismo en España, Madrid, Castalia. El volumen incluye también, en sus últimas páginas, una bibliografía-cronología de la cuestión evolucionista desde 1859 hasta 1900.

51 NúÑEZ, D. (1975), La mentalidad positiva en España: desarrollo y crisis, Madrid, Tucar. La obra conoció una reedición en 1987, sin apenas modificaciones, en Ediciones de la Universidad Autónoma de Madrid. El título fue ligeramente modificado, pues se quedó en $L a$ mentalidad positiva en España, a secas.

52 NúÑ̃Z (1975), pp. 163-198. 
— La utilización ideológica de la «teoría transformista» por el pensamiento liberal.

— La crítica socialista al uso burgués de la teoría.

De estas actitudes, surgían «dos frentes polémicos»:

- La contraposición entre pensamiento moderno, racionalista y secularizado, y pensamiento teocrático. Se trata de una confrontación muy extendida y que resulta central en el ámbito de análisis.

- La tensión entre la interpretación darwinista social del transformismo y las posiciones socialistas. Este enfrentamiento era mucho más matizado y coyuntural.

Núñez propugnaba utilizar el análisis de los primeros pasos del darwinismo en España como «baremo para detectar, en el plano de las ideas, el grado de desarrollo moderno de nuestro país $\rangle^{53}$. España, sin haber pasado por una genuina revolución burguesa equiparable a la de otras naciones europeas, no había experimentado los cambios económicos y culturales que hicieran de la ciencia un ente operante en la sociedad. El autor era quizá demasiado indulgente al juzgar que «en Inglaterra o Francia, por ejemplo, la crítica a la teoría transformista proviene de normales discrepancias en el escueto terreno científico, o de actitudes personales vinculadas a concepciones del mundo residuales y socialmente minoritarias $\rangle^{54}$. No obstante, tenía razón al señalar el peso ingente que los sectores tradicionales mantenían comparativamente en España, en todos los órdenes de la existencia.

Aunque Núñez admitía que el alejamiento español de la trayectoria histórica de la modernidad contaba con más matices, destacó básicamente dos: el enorme atraso del cultivo de las ciencias experimentales y el carácter escindido de la conciencia nacional. El abandono de la investigación experimental lo achacaba a la no consideración de la ciencia como factor productivo, en un punto en que seguía las tesis marxistas de John D. Bernal. En este punto, desde luego, coincidía plenamente con Glick, al remarcar que, salvo excepciones, el darwinismo no se discutió en el terreno de la ciencia, sino que se cayó en la disputa ajena a todo rigor científico y preñada de adjetivación gruesa. Sólo desde 1875, con una mayor receptividad a la filosofía positiva — aquí se

53 NúÑEZ (1977), p. 14.

54 NúÑEZ (1977). Especialmente en el caso francés, de gran complejidad, las críticas no se ciñeron a lo estrictamente científico, ni estuvieron protagonizadas siempre por representantes de sectores minoritarios; v. MolinA, G. (1996), Darwinisme français. En TORT, P. (dir.), Dictionnaire du darwinisme et de l'évolution, París, Presses Universitaires de France, pp. 909-954. 
aprecia su énfasis en el aspecto de la historia de las ideas-, se empezó a exigir en algunos círculos un mayor sentido crítico en la polémica darwinista ${ }^{55}$.

En cuanto a la escisión de la conciencia nacional, no era sino el reflejo de la división entre los vestigios supervivientes del Antiguo Régimen y los intentos por implantar el Nuevo. Las diferencias políticas subyacentes se ventilaban, también, en las esferas intelectuales y científicas. Según Núñez, el darwinismo ofrecía una explicación de la vida que chocaba frontalmente tanto «con los esquemas filosóficos escolásticos» como «con la interpretación literal de la Biblia, cosas ambas a las que andaba firmemente aferrada la Iglesia española» ${ }^{56}$. Esto último, dicho así, se antoja cuanto menos discutible, pues el literalismo bíblico estaba lejos de ser por entonces, y más en el mundo católico, lo que llegó a ser décadas después en algunos ámbitos peculiares del protestantismo. En cualquier caso, asumía Núñez la tesis de Aranguren de que el catolicismo español era, básicamente, un «catolicismo político», antiliberal y antimoderno. También, por supuesto, había en el liberalismo radical actitudes sectarias, que proclamaban la incompatibilidad absoluta entre catolicismo y saber científico. Ejemplificaba esta actitud en la acogida entusiasta de la obra de John William Draper y de su traducción en 1876, más el éxito editorial que luego cosechó ${ }^{7}$. No obstante, el mencionado autor también alcanzó amplia difusión en otros países científicamente más potentes ${ }^{58}$, por lo que el argumento de Núñez conserva un valor sólo parcial.

La principal línea argumental que Núñez contribuyó a asentar es, a nuestro juicio, la identificación de la polémica darwinista con la propia polarización ideológica de la conciencia nacional, de la que sería catalizadora como expresión pública de ella. La polémica sobre la evolución permitía detectar la escisión social que sacudía a un país atrasado. Era, claramente, el análisis ideológico el que ofrecía a Núñez la clave de comprensión social, como reconocía al asumir que la recepción del darwinismo en España daba «una excelente prueba de la rentabilidad analítica de la historia de las ideas para la cabal comprensión de la totalidad del proceso histórico» ${ }^{59}$.

55 NúÑ̃Z (1977), pp. 18-19.

56 NÚÑEZ (1977), p. 20.

57 NúÑEZ (1977), p. 23.

58 La tesis del conflicto inevitable entre ciencia y religión, que ejemplifican autores como Draper o Andrew Dickson White, se generalizó ampliamente desde el mismo momento en que éstos publican sus obras, y de hecho, no ha dejado de mantener una cierta influencia; v. RUSSELl, C.A. (2000), The conflict of science and religion. En FERngren, G.B., LARSON, E.J., AMUNDSEN, D.W., NAKHLA, A.M. (eds.), The history of science and religion in the western tradition: an encyclopedia, New York/London, Garland Publishing, pp. 12-16.

59 NúÑEZ (1977), p. 24. 
El estudio de Núñez incluye también una breve exposición de datos sobre el papel de médicos y naturalistas en la introducción de las ideas evolucionistas, más el de editores y traductores, junto a un repaso de los más célebres episodios de la polémica. Al contrario que Glick, Núñez no postula proceso alguno de normalización, pues señala cómo el paso de los años no evitó que el darwinismo siguiera siendo reflejo de la escisión ideológica de España; de modo que, si en la Segunda República habrá quien alardee de darwinismo para hacer ver su filiación izquierdista, así habrá quien tenga problemas durante la guerra por su darwinismo. "Y tras la guerra, un dato muy revelador: habrá que esperar a los años 60 para encontrar de nuevo ediciones castellanas de las obras de Darwin $»^{60}$. Finalmente, una sección sobre las proyecciones hacia lo filosófico del darwinismo, junto a sus lecturas ideológicas, con un resumen de las polémicas en torno al darwinismo social y la contestación marxista y anarquista, completaron la propuesta de Núñez, que abrió una fértil vía de exploración ideológica de la recepción de Darwin en España ${ }^{61}$.

Aunque ha gozado de menor difusión que las aportaciones de Glick y Núñez, una ojeada a la historiografía sobre el evolucionismo en España en los años setenta no debe dejar de lado la larga introducción de Francisco García Sarriá62 a su edición de las conferencias sobre el darwinismo que en 1887 pronunció Genaro García-Alas, hermano del novelista Leopoldo Alas «Clarín»" ${ }^{63}$. García Sarriá situaba el contexto de estas conferencias a través de una enumeración detallada de diversas contribuciones a la polémica darwinista en España durante los años previos, con especial énfasis en el aspecto religioso de la cuestión:

60 NúÑEZ (1977), p. 43.

61 En los años siguientes a la publicación de su libro, Núñez centró sus reflexiones en la relación entre marxismo y darwinismo; v. al respecto NúÑEZ, D. (1978), Unas relaciones malogradas: Marx-Darwin, Tiempo de Historia, 43, pp. 76-83, donde el autor indaga en la escueta relación que ambos autores mantuvieron a través de un exiguo cruce epistolar. En un plano más general se mueve NúÑEZ, D. (1980), Marxismo y darwinismo. En GARMA, S. (coord.), El científico español ante su historia: la ciencia en España entre 1750-1850. I Congreso de la Sociedad Española de Historia de las Ciencias, Madrid, Diputación Provincial de Madrid, pp. 519-526.

62 García Sarriá, F. (1978), Introducción. En El darwinismo. Conferencias pronunciadas en el Casino de Oviedo en los dias 25 de febrero, 4 y 11 de marzo, Exeter, University of Exeter, pp. V-LIII.

63 García Sarriá, estudioso de la novelística española contemporánea y por entonces en la Universidad de Edimburgo, era autor de un importante estudio sobre Clarín: GARCÍA SARRIÁ, F. (1975), Clarín o la herejía amorosa, Madrid, Gredos. Sobre la obra de García Sarriá, v. RiLEy, E.C. (1995), Francisco García Sarriá (1927-1994), Bulletin of Hispanic Studies, 72, pp. 215-216. 
«El darwinismo era un asunto que despertaba cierto escándalo y suscitaba oposición. No era ello por razones puramente científicas sino a causa del contexto histórico en que las ideas de Darwin, y la extensión y el uso que se hacía de ellas, venían a irrumpir. Me refiero, como es natural, al conflicto entre la Ciencia y la Religión (las mayúsculas aquí son de rigor) al que tantas páginas se dedicaron en Europa y que en España revistió un carácter especialmente agudo en parte a causa de la ausencia de un catoli[ci]smo liberal» ${ }^{64}$.

La historiografía del conflicto, de hecho, sigue presente en este trabajo de García Sarriá. Aunque hay partes del mismo que parecen querer situarnos en un contexto de mera percepción de conflicto por los propios polemistas del siglo XIX, a veces la distancia del autor aparenta diluirse, de modo que él mismo podría hacerse solidario con esa visión. En todo caso, García Sarriá ofrece datos de fuentes no utilizadas hasta la fecha por Glick o Núñez. Además, manifiesta ciertas reservas sobre la asunción de que es más bien Haeckel y no Darwin quien mayor interés estimuló en torno al evolucionismo entre los autores españoles. Esta idea, para la que cita a Juan López Morillas ${ }^{65}$, la critica en razón de las citas de Darwin y Haeckel en diversas fuentes de la época $\mathrm{y}$, también, a partir de las fechas de traducción de las obras de uno y otro ${ }^{66}$.

La polémica evolucionista también aparecía tratada por un autor tan eminente como Julio Caro Baroja en una colaboración en el volumen colectivo que se preparó en 1976 con ocasión del centenario de la Institución Libre de Enseñanza $^{67}$, y en el que el gran antropólogo relacionaba la «cuestión universitaria» de 1875 con la difusión del evolucionismo en España, y muy especialmente se fijaba en la actuación de Augusto González de Linares ${ }^{68}$. Joan

64 GARCía SARRIÁ (1978), pp. V-VI.

65 LóPez Morillas, J. (1956), El krausismo español: Perfil de una aventura intelectual, México, Fondo de Cultura Económica.

66 García SARriá (1978), pp. XI-XII.

67 CARo Baroja, J. (1977), «El miedo al mono» o la causa directa de la «cuestión universitaria», en 1875 [seguido de] Algunas noticias más sobre el origen de la «cuestión universitaria». En En el centenario de la Institución Libre de Enseñanza, Madrid, Tecnos, pp. 23-41.

68 El papel protagonista de González de Linares en la defensa pública del darwinismo fue vuelto a poner de relieve, años después, por Jaume Josa en una breve síntesis sobre la historia natural en la España decimonónica, en la que, por otro lado, trata muy de pasada los asuntos relacionados con el evolucionismo; v. JosA, J. (1992), La historia natural en la España del siglo XIX: botánica y zoología. En LóPEZ PIÑERO, J.M. (ed.), La ciencia en la España del siglo XIX, Madrid, Marcial Pons, pp. 109-152. Una valoración crítica de la mitificación de González de Linares, más en relación con su labor en pro de la institucionalización científica que con su defensa del darwinismo, en FrAGA, X.A. (1996), La institucionalización de la 
Senent-Josa, por su parte, dedicó un capítulo a la introducción del darwinismo en Cataluña en su librito sobre las ciencias naturales durante la Renaixença ${ }^{69}$, breve opúsculo que, en todo caso, marcó una referencia en los estudios sobre historia de los naturalistas catalanes.

\section{EL CENTENARIO DE LA MUERTE DE DARWIN: UNA CONMEMORACIÓN FRUCTÍFERA}

A tenor de lo que hemos expuesto, la historiografía del evolucionismo en España apenas si había empezado a constituirse, aunque se contaba ya con un puñado de referencias en las que situar los rasgos básicos de la polémica en torno a Darwin, su obra y su influencia en nuestro país, al menos en lo relativo al último tercio del siglo XIX. Aunque aún fuera un bagaje insuficiente, la débil comunidad de historiadores de la ciencia españoles llegó a 1982, año de la conmemoración del centenario de la muerte de Darwin, con al menos un marco básico y, por tanto, con cierto trabajo ya adelantado. De ahí que, efectivamente, ese año acabara por poder ser un punto de despegue para empresas de mayor fondo y alcance en cuanto a la elaboración de un discurso sobre la historia del evolucionismo en España. Al mismo tiempo, los especialistas españoles pudieron llegar, gracias a la conmemoración, a un público más amplio del acostumbrado, a través de diversas iniciativas editoriales encaminadas a difundir la figura, la obra y la influencia de Darwin. De este modo, se prepararon ediciones, algunas de ellas prologadas por historiadores de la ciencia, de obras del naturalista inglés, entre las que cabe destacar el facsímil de la traducción de Godínez del Origin en 1877; otro facsímil, este del Viatje d'un naturalista al rededor del mon de 1879 con un estudio preliminar de Josep Maria Camarasa, y una edición en catalán del Origin con prólogo de Glick $^{70}$. También se reeditó la historia de las teorías evolucionistas de Joaquín Templado $^{71}$. La prensa de información general también se hizo eco, de forma que Darwin ocupó espacio en las páginas de diarios como El País o La Vanguardia, como así mismo en el mítico semanario Triunfo. Y, naturalmente,

biología marina en España. El mito de González de Linares (1845-1904), Antilia, 2, artículo n ${ }^{\circ}$ 1 [www.ucm.es/info/antilia/ (17-8-2009)].

69 Senent-Josa, J. (1979), Les ciències naturals a la Renaixença, Barcelona, Dopesa 2.

70 Los detalles acerca de todas estas ediciones, en GoMIS, A., JosA, J. (2007), Bibliografía crítica ilustrada de las obras de Darwin en España (1857-2005), Madrid, CSIC.

71 Templado, J. (1982), Historia de las teorías evolucionistas, 2. edición, Madrid, Alhambra. 
las revistas culturales incluyeron a lo largo de aquel año artículos en torno al evolucionismo ${ }^{72}$. La barcelonesa $L$ 'Avenç dedicó el dossier de su número de abril, bajo la coordinación de Santiago Riera, a Darwin; entre otros, figuraba un artículo sobre la recepción del evolucionismo en Cataluña a cargo de José María Valderas, que incluía una detallada interpretación del célebre discurso de José de Letamendi en el Ateneo Catalán, opuesta en algunos puntos a la valoración que había merecido dicha pieza en diversas obras de referencia ${ }^{73}$.

En cuanto a las revistas de divulgación científica, hay que destacar para los propósitos del presente artículo que Mundo Científico, edición española de La Recherche, publicó una serie de artículos sobre historia del evolucionismo. Algunos de ellos eran colaboraciones de autores franceses, traducidas al español. No obstante, hubo también dos interesantes artículos de autores españoles ${ }^{74}$. Uno de ellos, de Diego Núñez, se ocupaba de la muerte de Darwin en la prensa española de la época ${ }^{75}$. El otro, de Josep Cuello Subirana, era una excelente crónica de la aceptación del darwinismo en España que primaba el acercamiento desde el punto de vista de los científicos y su obra, y no tanto de los polemistas con sus pasquines ${ }^{76}$. Cuello situaba la polémica, sin obviar las connotaciones ideológicas, en los propios términos que emplearon los que tenían argumentos que ofrecer desde el punto de vista de la ciencia de la vida, con especial atención precisamente a los naturalistas, quizá demasiado orillados hasta entonces por las síntesis más difundidas.

Para un público más especializado, la veterana Arbor prestó espacio a una nueva aproximación a la polémica darwinista en sus primeros momentos (entendiendo como tales, las dos primeras etapas de la propuesta de Glick, aunque sólo hasta 1874 para la segunda de ellas), desarrollada en un artículo de Juan Carlos Granados Cascos, no especialmente audaz en cuanto a sus planteamientos pero apreciable por el esfuerzo documental que atestigua su lista de fuentes, al ampliar la aportada en su momento por Núñez en El darwinismo en España ${ }^{77}$.

72 Valiosas referencias al respecto en BIBLIOGRAFÍA (1982), pp. 52-54.

73 VALDERAS, J.M. (1982), La recepció de la teoria evolucionista a Catalunya. Darwin i Letamendi, L'Avenç, 48, pp. 29-31.

74 También, una contribución bibliográfica; v. ANÓNIMO (1982), Traducciones españolas de las obras de Darwin, Mundo Cientifico, 2 (12), pp. 304-305.

75 NúÑEZ, D. (1982), La muerte de Darwin en la prensa española en 1882, Mundo Científico, 2 (13), pp. 396-404.

76 Cuello, J. (1982), Los científicos españoles del XIX y el darwinismo, Mundo Científico, 2 (14), pp. 534-542.

77 GranAdos, J.C. (1982), Los orígenes de la polémica darwinista en España, Arbor, 113 (441-442), pp. 151-173. 
La apuesta de conjunto más destacada fue seguramente la de la revista Anthropos, que consagró un número doble (un total de 96 páginas), publicado en el mes de octubre, al darwinismo en España. La portada ya era toda una declaración de intenciones, al presentar frente a frente los rostros silueteados de Darwin y Faustino Cordón (1909-1999), el bioquímico y biólogo evolutivo español, muy vinculado a la editorial Anthropos y a la revista homónima. La impronta de las ideas evolucionistas de Cordón era palpable a lo largo del número, con el editorial consagrado a ellas, más una selección de sus textos y una contribución de cierre escrita por él mismo. En lo relativo a la historia del evolucionismo, había una parte básicamente documental, en la que destaca la ya citada «Bibliografía hispánica sobre Darwin y el darwinismo» ${ }^{78}$; lo principal, sin embargo, se plasmaba en cinco artículos, agrupados en una sección de «Análisis y comentarios», en los que se abordaban diferentes aspectos de la historia del evolucionismo, no necesariamente circunscrita a España. De este modo, Mario García, de la Fundación para la Investigación sobre Biología Evolucionista (una entidad creada por Cordón), planteaba un balance comparado entre la biología de la época de Darwin y la del final del siglo XX, sin evitar ejercicios de historia contrafáctica ${ }^{79}$. El historiador Bernat Muniesa, de la Universidad de Barcelona, glosaba el impacto del darwinismo en el pensamiento social ${ }^{80}$, mientras que su colega José Florit Capella (ambos han llegado a ser catedráticos de historia contemporánea) resumía algunos aspectos de la introducción del darwinismo en España, remarcando de nuevo la polarización ideológica y reflexionando en torno a la creciente función referencial que el darwinismo fue adquiriendo como fundamentación discursiva ${ }^{81}$. Florit tomaba como referencia principal a Diego Núñez, quien por su parte contribuía en el monográfico con un trabajo acerca del impacto (de nuevo el impacto, recurso reiterado en otras aportaciones, como podremos ver) del evolucionismo en el liberalismo y el socialismo, en el que simultaneaba una descripción de la referencia general con un análisis sucinto del caso español, especialmente interesante en lo relativo a la influencia de la obra de Enrico Ferri entre los socialistas y las ambivalencias en la recepción del evolucionismo por parte de los anarquistas ${ }^{82}$. El otro gran referente de los estudios sobre la

78 BIBLIOGRAFÍA (1982).

79 GARcíA, M. (1982), Sobre Darwin, su época y la nuestra, Anthropos, 16-17, pp. 63-66.

80 MuniesA, B. (1982), El impacto del darwinismo en el pensamiento social, Anthropos, 16-17, pp. 81-84.

81 Florit, J. (1982), La introducción del darwinismo en España, Anthropos, 16-17, pp. 73-75.

82 NúÑEZ, D. (1982), El impacto del naturalismo y del evolucionismo en el pensamiento liberal y socialista, Anthropos, 16-17, pp. 66-72. 
historia del evolucionismo en España, Thomas Glick, también aportó una colaboración, la más original de las cinco, acerca del darwinismo en nuestro país en la primera mitad del siglo XX; en ella, valoraba la consolidación de programas evolucionistas en las facultades de medicina, básicamente por la obra de anatomistas, morfólogos y patólogos; así mismo, esbozaba los primeros pasos de la genética en España, especialmente a través de la obra de Antonio de Zulueta, de quien también mencionaba su vertiente de divulgador del evolucionismo; finalmente, daba interesantes noticias sobre la paleontología española posterior a la Guerra Civil, influida por Teilhard de Chardin, pero receptiva a un tiempo al neodarwinismo ${ }^{83}$.

En el mismo número de Anthropos ${ }^{84}$ se reseñaba el que, a la postre, ha acabado por ser el fruto más sustancioso de aquella cosecha historiográfica de 1982, al menos si atendemos al nivel de referencias alcanzado. Se trataba de un libro del propio Glick, Darwin en España, que Ediciones Península lanzó oportunamente al mercado en formato económico, dentro de una colección de bolsillo nutrida a partir de los fondos de diversas editoriales españolas ${ }^{85}$. El libro llevaba una introducción de José María López Piñero, en la que el catedrático de la Universidad de Valencia aprovechaba para cargar, con su característico estilo, contra la futilidad que suele envolver las conmemoraciones en torno al aniversario de una figura científica, como las que se estaban desarrollando en aquel momento con referencia a Darwin. López Piñero, no obstante, reconocía también que podían ser ocasión de aportaciones positivas; y el libro que presentaba era un ejemplo. Tras describir brevemente la trayectoria investigadora de Glick, revelaba el programa que éste estaba desarrollando con el objetivo de «conocer la forma en que la ciencia contemporánea se ha integrado en la sociedad española, analizando la recepción y difusión en la misma de la teoría de la relatividad, el darwinismo y el psicoanálisis», paradigmas, respectivamente, de las ciencias físicas, biológicas y humanas ${ }^{86}$.

Darwin en España es, sustancialmente, la traducción al español del estudio de Glick sobre el evolucionismo español aparecido originalmente en el volumen sobre la recepción comparativa del darwinismo ${ }^{87}$, junto a la adaptación resumida y traducción de la comunicación sobre el homenaje a Darwin en

83 GLICK, T.F. (1982a), El darwinismo en España en la primera mitad del siglo XX, Anthropos, 16-17, pp. 76-81.

84 ANÓNImo (1982), Thomas F. Glick. Darwin en España [reseña], Anthropos, 16-17, p. 8.

85 Glick, T.F. (1982b), Darwin en España, Barcelona, Península.

86 LóPEZ PiÑERO, J.M. (1982), Introducción. En GLick (1982b), Darwin en España, Barcelona, Península, pp. 9-11, cita en p. 11.

87 GLICK (1974b). 
Valencia en 1909, presentada, como ya se ha dicho, en el III Congreso Nacional de Historia de la Medicina ${ }^{88}$. Ambos estudios conforman, respectivamente, los dos capítulos en que se divide el librito, que de este modo ponía al alcance de un público amplio una parte sustancial de las investigaciones de Glick que habían quedado confinadas a los círculos especializados en razón de la vía de publicación y del idioma. En cualquier caso, Glick aportó también algunos materiales extra al conjunto. Ante todo, redactó un epílogo, ejemplo paradigmático de la orientación y el método característicos del autor, que tituló «El juicio de Dayton ante la opinión pública española»; en él, analizaba a través de la prensa el modo en que se siguió en España el célebre juicio celebrado en Tennessee contra el profesor John Scopes, en 1925, al tiempo que aprovechaba para establecer los puntos básicos de semejanza y de diferencia entre la cruzada protestante antievolucionista en los Estados Unidos y las polémicas españolas ante la recepción del darwinismo que había presentado en el conjunto del libro ${ }^{89}$. Por otro lado, añadió cuatro apéndices documentales, en los que publicaba, respectivamente, las nueve cartas que Peregrín Casanova mandó a Haeckel y que se conservan en la Ernst-HaeckelHaus de Jena, un relación de títulos evolucionistas y de autores librepensadores procedentes de la biblioteca del mencionado catedrático valenciano y custodiados en la Universidad de Valencia, una relación semejante de obras evolucionistas en la biblioteca de Baltasar Champsaur que habían quedado depositadas en el Museo Canario de Las Palmas, y tres cartas de Unamuno con motivo del homenaje a Darwin de 1909 en Valencia, de una colección particular pero que habían sido cedidas a la Universidad ${ }^{90}$.

Glick también ofreció ese año aportaciones al II Congreso de la Sociedad Española de Historia de las Ciencias, celebrado en la ciudad de Jaca, entre el 27 de septiembre y el 1 de octubre ${ }^{91}$. En concreto, pronunció una conferencia sobre la recepción del darwinismo en el mundo hispánico, donde una vez más hacía primar la perspectiva comparada, tomando el caso español como modelo frente al cual contrastaba el venezolano, el uruguayo, el argentino y el mexicano. Glick, siempre crítico con las interpretaciones que primaban el

88 GLICK (1971).

89 GLICK (1982b), pp. 69-79.

90 GLICK (1982b), pp. 81-104.

91 La referencia al centenario de la muerte de Darwin, además de por la selección de temas en las conferencias plenarias y por la definición de un área temática específica, según se relata inmediatamente, se pone de relieve gráficamente en el uso de un retrato de ancianidad del naturalista inglés en la portada de los volúmenes de las actas. 
acercamiento al darwinismo en estos contextos a través de la recepción del positivismo, rehusó en esta ocasión, expresamente, un enfoque de análisis de ideas para asumir una orientación típicamente social ${ }^{92}$. Como comunicación ordinaria, Glick expuso un segundo estudio, dedicado a la recepción del darwinismo en la Cuba anterior a la independencia ${ }^{93}$. Ciertamente, este congreso propició la presentación de un importante número de trabajos encuadrados dentro del área temática «Influencia del pensamiento de Darwin en España, Portugal y Latinoamérica». Las actas recogen 24 comunicaciones, 21 de ellas publicadas en extenso. Allí estaban representadas muchas de las orientaciones que los estudios sobre la historia del evolucionismo en España empezaban a manifestar: estudios sobre la postura de científicos concretos, el impacto en contextos regionales, la relación entre el evolucionismo y las disciplinas científicas, biológicas o no, los aspectos filosóficos y políticos, etc. ${ }^{94}$. El congreso, además, acogió conferencias plenarias sobre Darwin y el darwinismo, a cargo de Faustino Cordón ${ }^{95}$, el catedrático de filosofía del derecho Felipe González Vicén ${ }^{96}$, el historiador ruso Semion Mikulinsky ${ }^{97}$ y el conocido historiador de la ciencia argentino Eduardo Ortiz ${ }^{98}$, junto a la ya mencionada de Glick.

El análisis pormenorizado de estas tres decenas de aportaciones nos ocuparía mucho espacio, y por ello nos abstenemos de entrar en ello; algunas de ellas, en todo caso, serán citadas en otro momento. Ciertamente, y como no puede suceder de otra manera en estos casos, su valor particular es sin duda muy variable de unas a otras. Una apreciación conjunta, sin embargo, se impone: la conmemoración del centenario de la muerte de Darwin en este con-

92 GLICK, T.F. (1984a), Perspectivas sobre la recepción del darwinismo en el mundo hispano. En Hormigón, M. (ed.), Actas del II Congreso de la Sociedad Española de Historia de las Ciencias, Zaragoza, Sociedad Española de Historia de las Ciencias, vol. 1, pp. 49-64.

93 GLICK, T.F. (1984b), La polémica del darwinismo en Cuba. En Hormigón (1984), vol. 1, pp. 413-418.

94 HORMigÓN (1984), vol. 1, pp. 283-547.

95 Cordón, F. (1984), Significado de la aportación de Darwin a la biología y coyuntura científica que encuentra. En HORMIGÓN (1984), vol. 1, pp. 33-48.

96 GONZÁlez ViCÉn, F. (1984), El darwinismo social: espectro de una ideología. En HormigÓN (1984), vol. 1, pp. 65-79. González Vicén (1908-1991) fue autor de una amplia obra sobre filosofía del derecho y teoría del estado, en la que, entre otros muchos temas, analizó la contribución del positivismo en tales ámbitos. Una semblanza en DíAZ, E. (1991), Felipe González Vicén (1908-1991), Doxa. Cuadernos de Filosofía del Derecho, 9, pp. 23-38. 97 MikulinsKY, S.R. (1984), Diálogo a través de un siglo. En HorMigóN (1984), vol. 1, pp. 81-87.

98 ORTIZ, E.L. (1984), La polémica del darwinismo y la inserción de la ciencia en Argentina. En HORMIGÓN (1984), vol. 1, pp. 89-108. 
greso fue un factor clave para condensar líneas diferenciadas de trabajo sobre la historiografía del evolucionismo en España, sobre todo por parte de jóvenes investigadores con formación básica de científicos, que por entonces iniciaban su carrera como historiadores de la ciencia y que acabaron profesionalizándose como tales. Este hecho tuvo, según nos parece, un papel destacado en la consolidación de la historia de la biología, la geología y la historia natural en nuestro país, con un creciente estándar propio.

Recordemos que en el contexto internacional, la historia del darwinismo antes del centenario del Origen de las especies en 1959 fue escrita por historiadores de las ideas de formación básica diversa (historiadores generales, filósofos, etc.), o por biólogos convertidos circunstancialmente en historiadores, que basaban sus trabajos en los propios libros de Darwin y en los materiales diversos que generó su hijo Francis en diversos momentos. Desde los años sesenta, y sobre todo en los setenta, la cuestión darwinista pasó a ser tema central de una historia de la biología crecientemente diferenciada y profesionalizada ${ }^{99}$, que encontrará precisamente en la explotación de nuevas fuentes y la aplicación de nuevos métodos al estudio del darwinismo y del evolucionismo en general una vía privilegiada de consolidación disciplinar.

La historiografía del evolucionismo en España hasta 1982 estuvo protagonizada, como hemos visto, por autores con intereses amplios, pero decantados en no pocos casos hacia la historia de las ideas desde presupuestos conectados con las perspectivas más filosóficas o de análisis ideológico de las cuestiones estudiadas. El aspecto social que a veces afloraba atañía sobre todo a cómo esas ideas, o esos recursos filosóficos e ideológicos, habían penetrado en los movimientos y corrientes de opinión de la España de finales del siglo XIX (o, a lo sumo, de comienzos del XX), nutriendo una polémica aparentemente estéril en cuanto a la culturización científica del país, pero electrizante en cuanto a la toma de posición pública de personas, grupos e intereses. A partir de 1982, la nueva generación de estudiosos de la historia del evolucionismo enfocará crecientemente sus objetivos en una cuestión bastante orillada por los autores previos: el análisis del impacto, penetración o difusión (cambia el enfoque, pero no la orientación historiográfica) del evolucionismo en la práctica de los científicos españoles, y muy especialmente de los naturalistas, hasta entonces eclipsados por los autores médicos, que eran los que habían concitado la atención - $\mathrm{y}$ aun así, de modo colateral - hasta entonces. El propio concepto de evolucionismo se fue tomando en un sentido cada vez más amplio, diluyendo poco a

99 GLICK, T.F. (1989), Biologia i context social: la nova historiografia del darwinisme, Treballs de la Societat Catalana de Biologia, 40, pp. 7-18. 
poco la referencia hegemónica de Darwin; simultáneamente, se fueron perfilando más matices en cuanto a la identificación de unas u otras versiones del evolucionismo, incluidas aquellas más alejadas del propio darwinismo ${ }^{100}$. Las fuentes basadas en la prensa política o cultural generalista de las épocas estudiadas, o en las obras filosóficas, teológicas, políticas o sociológicas, se combinaron cada vez más con el análisis de la producción científica. Las aproximaciones, por último, fueron múltiples: desde el análisis de comunidades nacionales hasta las aproximaciones desde la particularidad local o personal, pasando por el enfoque disciplinar, la historia del evolucionismo en España pasó a ser un campo de estudio cada vez más plural y diversificado.

\section{LA COMUNIDAD CIENTÍFICA COMO REFERENCIA: EL EVOLUCIONISMO EN LOS BIÓLOGOS ESPAÑOLES DEL ÚLTIMO TERCIO DEL SIGLO XIX}

En el Congreso de Jaca estuvo presente, por más que no presentara comunicación alguna en la sesión sobre historia del evolucionismo, el investigador José Sala Catalá101, autor en aquella ocasión de dos trabajos, animados por una perspectiva declaradamente kuhniana, sobre la comunidad de biólogos españoles de finales del siglo XIX y comienzos del $X^{102}$. Sala ya andaba

100 La traducción del libro de Peter Bowler sobre el eclipse del darwinismo estimuló y ayudó, sin duda, en esta perspectiva matizada; v. BowLER, P.J. (1985), El eclipse del darwinismo. Teorías evolucionistas antidarwinistas en las décadas en torno a 1900, Barcelona, Labor. La obra original había sido publicada por Johns Hopkins University Press un par de años antes, lo que constituye un caso llamativo de celeridad en la traducción al español de una obra de historia del evolucionismo. Poco antes, había sido traducido el libro de Michael Ruse sobre la revolución darwinista, cuyo original es de 1979; v. RUSE, M. (1983), La revolución darwinista (La ciencia al rojo vivo), Madrid, Alianza, otra obra ampliamente utilizada y leída, y no sólo por los especialistas. En cualquier caso, sigue siendo reducida, hoy en día, la oferta al alcance del público hispano de obras extranjeras de referencia en cuanto a la historia del evolucionismo.

101 Nacido en Alicante, José Sala Catalá (1954-1991) se doctoró en ciencias biológicas con una tesis de contenido neurobiológico. Su carrera, sin embargo, acabó por decantarse hacia la historia de la ciencia, campo en el que se interesó no sólo por la historia de la biología y el evolucionismo en España, sino también por la ciencia en la América colonial. Una aproximación a la obra de Sala en CAPEl, H. (1994), Prólogo. En SAlA, J., Ciencia y técnica en la metropolización de América, Madrid, CSIC/Doce Calles, pp. 7-21. V. también AlBARRACín, A. (1992), José Sala Catalá, In Memoriam, Asclepio, 44 (1), pp. 369-372, y PeSET, J.L. (1992), José Sala Catalá (9 de noviembre de 1954-23 de diciembre de 1991). In Memoriam, Dynamis, 12, pp. 151-153.

102 SAla, J. (1984a), Conflictos y paradigmas en la biología de la segunda mitad del siglo XIX. En Hormigón (1984), vol. 3, pp. 277-291; SALA, J. (1984b), Los biólogos españoles 
trabajando, desde hacía algún tiempo, en la cuestión. Fue en 1981 cuando presentó su ambicioso programa de investigación, en un artículo aparecido en la revista Asclepio dedicado al evolucionismo en la práctica científica de los biólogos españoles entre 1860 y $1910^{103}$. Sala proponía que dicha práctica se podía caracterizar apelando a un contexto de revolución científica —el evolucionismo darwinista - en el cual entrarían en conflicto dos paradigmas rivales. Su pretensión explícita era "realizar una buena descripción de lo que Th.S. Kuhn designó con el nombre de 'revolución científica'»104. En coherencia con este programa, Sala caracterizaba un «paradigma evolucionista», fundamentado en los principios de adaptación y de selección natural, que entraba en conflicto con un «paradigma oficial», cuya característica primordial era apelar a las leyes de la armonía funcional y de la armonía de faunas y floras, o planes de la Creación. Con todo esto, pretendía mostrar cómo la progresiva difusión e implantación del primero conducía a un conflicto social y político, cuya base estaba en la discusión ideológica y en las maniobras por el establecimiento y control de los medios de comunicación científica y de institucionalización de la biología en España. Al año siguiente, en la misma revista, Sala planteó una primera revisión de su propuesta, tras reconocer que las denominaciones «oficial» y «evolucionista» resultaban vagas e inadecuadas. Rechazó la primera por encontrarla «poco explícita de las posibilidades investigadoras a que me quiero referir» y la segunda por tener «el defecto de referir la idea de evolución del organismo vivo a la obra exclusiva de Darwin», cuando él quería poner de manifiesto que se encontraba ya en la biología anterior a Darwin, además de que «tiende a referirse exclusivamente al campo de la Historia Natural, siendo que, como he pretendido demostrar, el cambio paradigmático también acontece en disciplinas biológicas puramente experimentales como la Fisiología y la Embriología» ${ }^{105}$. Tal vez Sala podría haber usado argumentos más sencillos para justificar lo inadecuado de la denominación "paradigma oficial»; básicamente, ésta no es comparable a «evolucionista» porque se encuentra en un plano de significación diferente. «Oficial» lleva una carga semántica aplicable a múltiples aspectos de la realidad, de modo

entre 1860 y 1922: una sociedad científica en cambio. Su descripción. En HoRMIGÓN (1984), vol. 2, pp. 379-410.

103 SALA, J. (1981), El evolucionismo en la práctica científica de los biólogos españoles del siglo XIX, Asclepio, 33, pp. 81-125.

104 SALA (1981), p. 82.

105 SAla, J. (1982), Cambio de paradigma y polémica científica entre los biólogos españoles (1860-1922), Asclepio, 34, pp. 239-263, cita en pp. 240-241. 
que viola el ámbito mucho más restringido a la teoría y práctica científicas que se asocia a «evolucionista». Hay otras posible críticas, igualmente evidentes, pero más de fondo. ¿Por qué aseguraba Sala que «evolucionista» hacía referir la evolución a Darwin? Aún más, ¿cómo podía justificar que «evolucionista» tendía a referirse exclusivamente a la historia natural? Como hemos visto, ya estaba demostrada la fuerte impregnación evolucionista de disciplinas no precisamente de historia natural durante el período considerado, como era el caso de varias disciplinas médicas básicas, muchas de las cuales, por cierto, él mismo tomó en consideración en cuanto ramas de la biología. Sea como fuere, Sala propuso un cambio en la denominación de los paradigmas al tiempo que una redefinición. De esta manera, pasó a hablar de un "paradigma fisiológico», según el cual la función de los órganos es esencial en el mantenimiento de la vida orgánica, y un «paradigma ecológico», que sostiene que la vida se mantiene por la capacidad que muestran los organismos para adaptarse a los distintos ambientes. Lograba así eliminar la distorsión entre planos de significación. Pero, sin embargo, inducía a cierta confusión con los términos escogidos, al quedar claro que casi nadie practicó la fisiología en España según el «paradigma fisiológico» ${ }^{106}$, y apenas hubo en nuestro país investigación ecológica stricto sensu, lógicamente referida al «paradigma ecológico», hasta la segunda década del siglo $\mathrm{XX}^{107}$.

Los tiempos de cambio de paradigma fueron estudiados por Sala en una de las comunicaciones del Congreso de Jaca, en la que proponía una periodización tal, que entre 1860 y 1875 habría dominado el paradigma fisiológico, entre 1875 y 1887 se habría vivido la división de la comunidad científica, desde 1887 habría empezado a predominar paulatinamente el paradigma ecológico, hasta que en 1909 ya sería éste completamente dominante ${ }^{108}$. Sala, por tanto, mantenía el año 1875 como la gran referencia para la activación máxima de la polémica evolucionista en España, y mantenía el valor simbólico de 1909 como referencia de normalización del evolucionismo en nuestro país: el proceso de cambio habría llegado a un punto en que el paradigma emergente

106 De hecho, en una de las comunicaciones presentadas en Jaca, postuló que la implantación definitiva del paradigma ecológico en España a partir de 1909 fundó la práctica de nuevas disciplinas, de las que destacaba expresamente la biología marina y la propia fisiología (SALA (1984b)).

107 Una crítica en la que abunda con más detalles CASADO, S. (1998), La Ecología y la conservación de la naturaleza en la historia de la Real Sociedad Española de Historia Natural, Memorias de la Real Sociedad Española de Historia Natural, (2. 'época), 1, pp. 159-180.

108 SALA (1984b). 
había sustituido en la práctica biológica ordinaria al antes dominante. El esfuerzo de Sala fue muy considerable, pues se fundamentaba en el análisis del conjunto de la producción impresa en biología (tomado el concepto en el sentido actual ${ }^{109}$ ) durante el período, lo que en total supondría cerca de 2400 trabajos. Otra cuestión sería si los criterios adoptados para asignar cada trabajo a uno u otro paradigma eran los más adecuados en cuanto a su fundamentación teórica o a su simple aplicabilidad, cuestión que, desde luego, nos llevaría más allá de nuestras pretensiones ${ }^{110}$. Por otro lado, surge una duda importante: si la adaptación era para Sala, según hemos visto, el rasgo fundamental del «paradigma ecológico», ¿cómo podría resultar éste dominante en España en un momento en que precisamente las opciones intrínsecamente adaptacionistas en la explicación de la evolución pasaban, en el conjunto de la comunidad científica internacional, por una situación de marginación? ${ }^{111}$. En este mismo trabajo, Sala ofrecía una serie de «tablas de investigadores» según disciplinas concretas con el propósito de «descubrir la ubicación metodológica e institucional del investigador, así como la continuidad de su trabajo» ${ }^{112}$, que evocan a las redes de investigación que N.C. Mullins construyó en su trabajo sobre la historia del estudio de los bacteriófagos ${ }^{113}$. Una red de este estilo describe la estructura de una comunidad científica durante un período; conseguir una descripción de las comunidades especializadas en la biología española era también, básicamente, lo que perseguía Sala. Sus tablas estaban construidas colocando los nombres de los investigadores en función de un eje temporal. Además, disponía a uno u otro lado de una línea paralela al eje estos nombres, en función de la adscripción a uno u otro paradigma. Tras esto, proyectaba los agrupamientos en otro eje también paralelo sobre el que colo-

109 Una crítica a la demarcación disciplinar adoptada por Sala, en CATALÁ, J.I. (2001), La historia natural y los naturalistas en la España contemporánea: algunos problemas de delimitación conceptual, Ingenium, 7, pp. 131-140.

110 Otra crítica, puntual, acerca de una de esta asignaciones, en CASADO, S. (1997), Los primeros pasos de la ecología en España, Madrid, Ministerio de Agricultura, Pesca y Alimentación/Publicaciones de la Residencia de Estudiantes, pp. 171-172.

111 BOWLER (1985).

112 SALA (1984b), p. 385.

113 Referido en KRAGH, H. (1989), Introducción a la historia de la ciencia, Barcelona, Crítica, pp. 229-230, donde este autor caracteriza el estudio del desarrollo de las comunidades y disciplinas científicas como un género historiográfico que se interesa por la génesis, desarrollo y desintegración de aquéllas, por su estructura social, por las «bases paradigmáticas» de tales disciplinas, por los miembros de las comunidades y sus relaciones en el seno de ellas, etc. Un género, pues, al que se ajustaban razonablemente bien el método y los objetivos de Sala. 
caba lo que él denominaba instituciones científicas ${ }^{114}$. El resultado, aunque un poco complicado en su plasmación gráfica, era bastante atractivo y, a priori, útil a la hora de ubicar a un personaje en relación con sus colegas. Sin embargo, se planteaba inmediatamente una objeción: ¿qué hacer con un personaje cuya obra se adscribe a un determinado paradigma sólo hasta determinada fecha? Puede suceder, en efecto, que a partir de esa fecha las publicaciones de ese autor acusen un cambio paradigmático. Esto no se reflejaba en las «tablas», a pesar de dar cuenta de autores en los que se había demostrado un cambio de orientación teórica o metodológica que, si se aplicaban los criterios de Sala, vendrían a ser expresión de un cambio de paradigma. Él mismo citaba el caso de José Joaquín Lánderer, aunque de manera sorprendentemente mudable de unas publicaciones a otras; así, en unos momentos lo describía como cuvieriano estricto y defensor incondicional del paradigma fisiológico en paleontología, al tiempo que decía que a lo largo de su obra llegó a admitir la extinción de las especies al azar y buscó conciliar esta postura con dicho paradigma ${ }^{115}$. En trabajos posteriores, lo presentaba como «inspirador principal del programa» de conciliación de catolicismo y evolucionismo que dio lugar a la denominada escuela geológica catalana, receptiva al paradigma ecológico ${ }^{116}$, y como personaje que «acepta críticamente el evolucionismo» ${ }^{117}$. La dificultad de caracterización de las posturas ante el evolucionismo entre los autores españoles eran, pues, un serio obstáculo en el planteamiento un tanto rígido de las tablas de Sala ${ }^{118}$.

114 Hasta 30 instituciones llegó a reconocer, para el período 1850-1923, dedicadas a la investigación biológica en España, las cuales «cohesionaron un asociacionismo científíco muy importante»; v. SALA, J. (1985), Previsiones ideológicas en la institucionalización de la investigación biológica en España durante el siglo XIX. En PESET, J.L. (coord.), La ciencia moderna y el Nuevo Mundo, Madrid, CSIC, pp. 327-347, cita en p. 327.

115 SALA $(1981,1982)$.

116 SALA (1985), p. 331.

117 Sala, J. (1987a), Ideología y Ciencia Biológica en España entre 1860 y 1881. La difusión de un paradigma, Madrid, CSIC, p. 31.

118 Otra objeción, similar a la que introduce Kragh al valorar las redes de Mullins, también se hace patente: los criterios en la delimitación de disciplinas. Si se cambia el criterio, la apariencia de las redes cambia y, sobre todo, cambian los nombres que aparecen en ellas. Esto no es una cuestión trivial en el contexto específico de las ciencias naturales españolas de la época. Sala estableció una división por materias de la «biología» ciertamente discutible, división que aplicó muy rígidamente en su estudio de las publicaciones. Así, hablaba de taxonomía, paleontología, biogeografía, morfología y físiología, más un curioso agregado, denominado extrañamente «biología», que comprendía la ecología, la microbiología y la parasitología, y para el que no aducía otra razón de constitución que el común interés en las 
La otra comunicación presentada por Sala al Congreso de Jaca tuvo un cariz más teórico, y en ella asentó su concepto de paradigma. Tras describir varias polémicas científicas acontecidas en la segunda mitad del siglo XIX, se reafirmaba en la propuesta de los dos paradigmas, el fisiológico, fuertemente implantado institucionalmente hacia 1850, y el ecológico, que irrumpió con la publicación del Origin de Darwin en 1859. Por cuanto los conflictos relatados se fundamentaban en la no coincidencia de campos observacionales — según se tomara en consideración la función o la adaptación para explicar la conservación de los organismos-, se podía a su vez fundamentar una definición historiográfica, aunque no filosófica, suficiente de paradigma, por la explicitación del campo observacional de referencia. Es decir, que entendía Sala el concepto de paradigma «no tanto referido a una teoría, sino al esquema de actos supuestos en su producción y que en último término tienen como punto de partida un determinado campo observacional» ${ }^{119}$. Esta matización del concepto de paradigma quedó formalizada en la obra más importante de Sala, su libro Ideología y Ciencia Biológica en España entre 1860 y 1881. La difusión de un paradigma. Publicado en 1987, incluye precisamente, además de una reacotación del período de estudio, en este caso para reducirlo, una nueva formulación de su idea de paradigma: «Un nuevo 'paradigma' o modelo a imitar no es tanto una o varias teorías científicas, como una práctica investi-

condiciones de adaptación del organismo al medio. Esta rigidez ocasionaba paradojas. Un ejemplo claro es Eduardo Boscá, a quien se le reconoce una aportación zoogeográfica muy notable por sus estudios herpetológicos; v. al respecto FRAGA, X.A. (1989a), A modernización da Taxonomia herpetológica a fins do XIX no Estado Español: as aportacións de Boscá e López Seoane, Treballs de la Societat Catalana d'Ictiologia i Herpetologia, 2, pp. 26-43. Boscá, sin embargo, no aparece en la tabla de investigadores en biogeografía que construyó Sala, puesto que tales trabajos herpetológicos quedaron asignados a la taxonomía. Boscá es ejemplo también de autor en el que, como en el caso de Lánderer, hay una mudanza en la adscripción a paradigmas que no se refleja en las tablas de Sala. En su última aportación a la historia de las ciencias naturales en España durante la Restauración, Sala citó expresamente a Boscá como uno de los «jóvenes estudiantes del doctorado de ciencias bajo el magisterio de Giner, [que] entre 1867 y 1874 evolucionan desde una rígida visión anatomizante del organismo hasta una visión adaptativa»; v. SALA, J. (1988), Ciencia biológica y polémica de la ciencia en la España de la Restauración. En SÁnCHEz Ron, J.M. (ed.), Ciencia y sociedad en España: de la Ilustración a la Guerra Civil, Madrid, CSIC/El Arquero, pp. 157-177, cita en p. 163. De hecho, Xosé A. Fraga ha descrito el cambio que acontece en la obra herpetológica de Boscá haciendo uso de la propuesta paradigmática de Sala, y muestra claramente cómo los primeros trabajos de aquél eran expresión de los modos tradicionales de plantear la taxonomía herpetológica (FRAGA (1989a)).

119 SALA (1984a), p. 288. 



que desde los manifiestos de fe kuhniana de sus primeras obras a la definición citada hay un salto cualitativo muy notable en la trayectoria del autor. Y aun sabiendo que Kuhn utiliza el término "paradigma» en más de un sentido, es inevitable que, al primer golpe de vista - aunque luego quedara mucho por matizar - esta definición de Sala nos evoque los «programas de investigación» de Lakatos.

La aportación básica del libro de Sala era la división con criterio ideologista de la comunidad de biólogos españoles, entre 1868 y 1881, en seis grupos: krausistas, positivistas, neotomistas, eclécticos, moderados y materialistas. Una división que Sala ya había avanzado en su participación en la I Reunión de Historia de la Ciencia y de la Técnica de los Países Ibéricos e Iberoamericanos, celebrada en Madrid en septiembre de 1984, y que asignaba en este caso a un período de tiempo mucho menos definido, puesto que hablaba, en general, del siglo XIX. Presentaba en principio los cinco grupos - excluía los materialistas por tratarse de un conjunto poco coherente de personalidades aisladas cuya postura no llegó a institucionalizarse - como las «previsiones ideológicas» que permitían definir lo que él mismo denominaba «conjunto de la polémica científica que abarcó el asociacionismo científico español del siglo XIX por lo que a Ciencias Biológicas se refiere» ${ }^{121}$. En esta aportación, Sala incidía especialmente en el soporte institucional que había hallado o promovido cada «previsión ideológica». Por el contrario, en el libro puso el énfasis en los medios de comunicación de que se valía cada «grupo» para difundir sus ideas. Mucho habría que discutir sobre los criterios que utilizó Sala para establecer estos grupos. La práctica revela que no es fácil, en muchos casos, asignar cada autor concreto. De hecho, los solapamientos ideológicos no son infrecuentes, sobre todo en las personalidades menos relevantes. También se podría comentar por extenso la fortuna de algunas de las denominaciones adoptadas. En cualquier caso, fue un intento honrado de poner orden en el cúmulo de etiquetas dispares que alegremente se venían aplicando a los biólogos españoles de la época contemporánea.

Sala, por supuesto, supeditaba la caracterización de cada grupo a la postura pertinente ante el paradigma ecológico. De este modo, krausistas, positivistas, eclécticos y materialistas, cada uno con sus matices, aceptaban el paradigma ecológico (y, correlativamente, el evolucionismo). De los moderados, soste-

120 SALA (1987a), p. 11.

121 SALA (1985), p. 337. 
nía que rechazaban «las teorías características del paradigma ecológico» ${ }^{122}$, lo cual no se avenía con su reformulación del concepto de paradigma, contenida en la misma obra, al volver a presentar las teorías, y no las prácticas de investigación, como los elementos principales de la caracterización.

La valiente propuesta de Sala, ejemplo de proceder historiográfico comprometido y ambicioso, topó, básicamente, con la gran dificultad que suponía una descripción general de la comunidad de «biólogos» españoles durante la Restauración. Era inviable, en el estado de las investigaciones de la época, acometerla con un grado de precisión y detalle tan elevado como el que el propio autor anhelaba, toda vez que faltaban aún muchos estudios tanto sobre los saberes científicos como sobre la organización social de los cultivadores de la historia natural y de la biología, tanto para el conjunto de España como para ámbitos locales. Un problema no menor era, precisamente, la falta de detalle que se padecía en la caracterización de las ideas evolucionistas en España. En algún momento habrá de recuperarse el arrojo que tuvo Sala y plantear un estudio con esa orientación general y sintética. En aquel momento, sin embargo, resultó prematuro, aunque su propuesta haya podido servir como punto de apoyo para debates sobre la incorporación de la perspectiva evolucionista en la práctica de los naturalistas y biólogos españoles.

\section{LA VÍA MEDIA: ENTRE LA HISTORIA DISCIPLINAR Y LA DE LAS IDEOLOGÍAS}

La aproximación a través de la historia disciplinar podía obviar el que tal vez era el problema principal de partida del programa de Sala: la dificultad de manejar adecuadamente un volumen de fuentes inmenso y diverso. Por otro lado, un análisis centrado en las disciplinas daría una interpretación ajustada a las peculiaridades de cada caso del modo en que el evolucionismo se fue incorporando a las prácticas de los científicos españoles, al tiempo que permitiría aquilatar hasta qué punto fue clave en la consolidación de cada disciplina.

Una de las disciplinas más tempranamente beneficiadas por los estudios de la nueva generación de historiadores de la ciencia, y que al mismo tiempo planteaba un caso evidente de conexión con la historia del evolucionismo, fue la antropología. Su proceso de constitución e institucionalización ya había recibido atención por parte de Elvira Arquiola, especialista en el caso francés ${ }^{123}$, que

122 SAla (1987a), p. 31.

123 V., entre otros muchos trabajos, ARQuiola, E. (1978-1979), Anatomía y antropología en el positivismo francés, Asclepio, 30-31, pp. 19-32. 
también estudió la tensión entre anatomía y antropología física en España, sin abordar, no obstante, la cuestión evolucionista ${ }^{124}$. Este asunto sí se trató en el mencionado Congreso de Jaca, en una comunicación sobre la presencia darwinista en la Sociedad Antropológica Española125; sus autores eran Andrés Galera, Miguel Ángel Puig-Samper y Francisco Pelayo, tres jóvenes investigadores que estaban iniciando entonces su carrera como historiadores de la ciencia $^{126}$. Los dos primeros publicaron poco tiempo después un pequeño pero notable libro, el primero de la serie «Cuadernos Galileo de Historia de la Ciencia», donde estudiaban la práctica e institucionalización de la antropología española en el siglo XIX ${ }^{127}$. La fundación de la Sociedad Antropológica Española en 1865 debía mucho a la inquietud intelectual suscitada por el evolucionismo ${ }^{128}$, y desde luego, la reactivación de su labor a partir de 1874 se vio alentada por las polémicas evolucionistas, presentes también en otros círculos de estudio antropológico de la época ${ }^{129}$. El caso catalán, por su parte, fue estudiado por Luis Calvo en su tesis doctoral, centrada sobre todo en el desarrollo de la antropología cultural ${ }^{130}$, si bien este autor también se ha ocupado específicamente en algún trabajo de la antropología biológica, aportando algunos datos sobre polémicas relacionadas con el evolucionismo y valorando la influencia de Darwin y Haeckel en el desarrollo de un modelo naturalista de investigación

124 Arquiola, E. (1981), Anatomía y antropología física en el positivismo español, Asclepio, 33, pp. 3-22.

125 Galera, A., Puig-Samper, M.A., Pelayo, F. (1984), El darwinismo en la Sociedad Antropológica Española. En HORMIGÓN (1984), vol. 1, pp. 389-402. En la misma reunión científica, José Luis Peset también se ocupó de las reacciones ante el darwinismo desde la antropología, pero para el caso británico; v. PESET, J.L. (1984), La Sociedad Antropológica de Londres y el antidarwinismo. En HORMIGÓN (1984), vol. 1, pp. 489-512. No fueron tampoco las únicas aportaciones sobre historia de la antropología; v. ARQUiOLA, E. (1984), La Antropología en la obra de Letamendi. En Hormigón (1984), vol. 2, pp. 31-46, y FrAnCÉS, J.L. (1984), Telesforo de Aranzadi y Unamuno, un farmacéutico dedicado a la Antropología. En HoRMigón (1984), vol. 2, pp. 105-114.

126 Gomis, A., JosA, J. (2003), Veinticinco años de Historia de la Biología en España (1977-2002), Llull, 26, pp. 109-156, p. 113.

127 Puig-Samper, M.A., GalerA, A. (1983), La Antropología española del siglo XIX, Madrid, CSIC.

128 Cuestión también tratada en Puig-SAMPER, M.A. (1982), El doctor Pedro González de Velasco y la antropología española en el siglo XIX, Asclepio, 34, pp. 327-337.

129 PUig-SAMPer, GALERA (1983), pp. 34-46.

130 Calvo, L. (1990), La antropología en Cataluña (1915-1970), Barcelona, Universitat de Barcelona (hay edición en microficha, 1991). 
antropológica en España ${ }^{131}$. En cuanto a la presencia del evolucionismo en la antropología criminal española, influida por las teorías de Cesare Lombroso, fue una cuestión tratada por Andrés Galera ${ }^{132}$.

La historia de las disciplinas biológicas experimentales también ha llevado a valoraciones históricas del evolucionismo desde enfoques distintos. Jorge Navarro, estudioso de los orígenes de las ciencias del sistema nervioso en España, de los que se ocupó en su tesis doctoral ${ }^{133}$, exploró con gran sutileza los aspectos evolucionistas relacionados con tal cuestión, interesándose sobre todo por el período predarwinista y detectando las influencias en nuestro país de autores como Cabanis, Etienne Geoffroy Saint-Hilaire o los morfólogos idealistas alemanes ${ }^{134}$. Las neurociencias también reclamaron la atención de Luis Alfredo Baratas, en el contexto más amplio de sus investigaciones sobre el desarrollo de la biología experimental en España durante el último tercio del siglo XIX y el primero del XX. Baratas revisó la influencia del krausismo en la enseñanza universitaria de la ciencia, atendiendo desde luego a la postura ante las teorías evolucionistas ${ }^{135}$. También se ocupó de la constitución de la escuela neurohistológica española, de la fundación del laboratorio de fisiología general, vinculado a la labor de Juan Negrín, y de la presencia institucio-

131 CAlvo, L. (1990), La antropología biológica en Cataluña, Llull, 13 (25), pp. 321-348. V. también CALVO, L. (1997), Historia de la antropología en Cataluña, Madrid, CSIC, pp. 32-43.

132 Galera, A. (1991), Ciencia y delincuencia. El determinismo antropológico en la España del siglo XIX, Madrid, CSIC.

133 La dirección de José María López Piñero pudo ser un estímulo fundamental en el interés por las cuestiones evolucionistas que se manifiesta en los trabajos de Navarro. Recordemos que López Piñero había prestado ya atención al papel de las doctrinas evolucionistas en la conformación de las ciencias médicas básicas contemporáneas; v., por ejemplo, LÓPEZ PIÑERO, J.M. (1973), La morfología comparada anterior a Darwin y la interpretación iatrocéntrica de la historia de la anatomía. Medicina Española, 69, pp. 9-34; LóPEZ PIÑERO, J.M. (1973), La anatomía comparada evolucionista y su penetración en la ciencia del cuerpo humano. En LAín, P. (dir.), Historia Universal de la Medicina, Barcelona, Salvat, vol. 6, pp. 29-35. Específicamente relacionado con las neurociencias, LÓPEZ PIÑERO, J.M. (1973), John Hughlings Jackson (1835-1911). Evolucionismo y Neurología, Madrid, Moneda y Crédito.

134 Navarro, J. (1987), Aspectos evolucionistas en los orígenes de las neurociencias en España, Arbor, 497, pp. 103-124; NAVARro, J. (1988), Aspectos evolucionistas en los orígenes de las neurociencias en España. En Valera, M., EgeA, M.A., BlÁzquez, M.D. (ed.), VIII Congreso Nacional de Historia de la Medicina. Libro de Actas, Murcia, s.d., vol. 1, pp. 2-15.

135 También se ocupó de cuestiones próximas SALA, J. (1987b), Enseñanza e investigación biológica en la Universidad de la Restauración (1875-1923). En Universidades españolas y americanas, Valencia, Generalitat Valenciana, pp. 505-518. 
nal de la genética en la Junta para Ampliación de Estudios ${ }^{136}$. Precisamente la historia de la genética, ha sido intensamente estudiada por Susana Pinar, que ha analizado, entre otros asuntos, la introducción y desarrollo de las teorías de la genética moderna en España, de la mano de personajes como José Fernández Nonídez y Antonio de Zulueta ${ }^{137}$. En relación con el evolucionismo, la labor científica, docente y de publicista de este último fue fundamental para la divulgación crítica de las teorías mutacionistas-saltacionistas en España, así como para el mantenimiento de una perspectiva abierta y viva sobre el propio darwinismo - sin adhesiones incondicionales - en los años en que el cuestionamiento de sus principios era norma general ${ }^{138}$.

Fuertemente relacionados con aspectos de la articulación del discurso científico en la medicina contemporánea, y trascendiendo en mucho el ámbito estricto de la historia del evolucionismo, encontramos los numerosos trabajos de Raquel Álvarez Peláez sobre historia de la eugenesia, tanto en España ${ }^{139}$

136 BARATAS, L.A. (1997), Introducción y desarrollo de la biología experimental en España entre 1868 y 1936, Madrid, CSIC.

137 PINAR, S. (1999a), José Fernández Nonídez, introductor de la teoría mendelianocromosómica en España, Asclepio, 51 (1), pp. 27-54; PINAR, S. (1999b), La introducción de la genética en España durante el primer tercio del siglo XX, Llull, 22, pp. 453-473; PINAR, S. (2002), The Emergence of Modern Genetics in Spain and the Effects of Spanish Civil War (1936-1939) on its Development, Journal of the History of Biology, 35 (1), pp. 111-148.

138 La figura de Zulueta y la institucionalización de la genética han sido estudiadas también por VALDERAS, J.M. (1988), La genética en la JAE. Antonio de Zulueta y Escolano (1885-1971). En SÁNCHEZ Ron, J.M. (coord.), 1907-1987. La Junta para Ampliación de Estudios e Investigaciones Científicas 80 años después. Simposio Internacional, Madrid, CSIC, vol. 2, pp. 401-428. Años antes se defendieron las memorias de investigación de CARBONELL, F. (1977), La introducción de la genética mendeliana en España (1901-1935), Universidad de Valencia, tesis doctoral inédita, y de GARCíA MARTínEZ, J. (1984), Aportaciones a la historia de la genética española, Universidad Complutense de Madrid, tesis de licenciatura inédita.

139 Para nuestros propósitos, v. especialmente Álvarez PelÁEZ, R. (1985), Introducción al estudio de la eugenesia española. Quipu, 2, pp. 95-122; Álvarez PelÁEz, R. (1985), La eugenesia en España, Mundo Científico, 5 (48), pp. 622-629; Álvarez Peláez, R. (1988), Origen y desarrollo de la eugenesia en España. En SÁNCHEZ Ron, J.M. (ed.), Ciencia y sociedad en España: de la Ilustración a la Guerra Civil, Madrid, CSIC/El Arquero, pp. 179-204; Álvarez Peláez, R. (1988), Eugenesia y control social, Asclepio, 40 (2), pp. 29-80; ÁlvaREZ PELÁEZ, R. (1997), Eugenesia y fascismo en la España de los años treinta. En HuerTAS, R., Ortiz Blanco, C. (coord.), Ciencia y fascismo, Aranjuez, Doce Calles, pp. 77-96; ÁlvARez Peláez, R. (1998), Medicina, genética y eugenesia en la España del primer tercio del siglo XX. En Castellanos, J., JimÉnez Lucena, I., Ruiz Somavilla, M.J. (ed.), Medicina en el siglo XX: estudios históricos sobre medicina, sociedad y estado, Málaga, Universidad de Málaga, pp. 363-372. 
como en otros países ${ }^{140}$. Aunque desde una perspectiva actual acentuamos el carácter doctrinal de la eugenesia, lo cierto es que, en su contexto, se reveló como una corriente a la búsqueda de institucionalización ${ }^{141}$, lo que permite aplicarle muchos de los métodos propios de la historia disciplinar. El conjunto de la aportación de Álvarez pone de manifiesto la relevancia que, a través de la eugenesia, tuvo la difusión del evolucionismo en el desarrollo de las doctrinas médico-sociales y, obvio es decirlo, el intenso uso ideológico, desde posturas además muy diversas, que padeció. De hecho, el caso de la eugenesia en España prueba cómo, hacia comienzos del siglo XX, ser de derechas o, incluso católico, no va a ser ya impedimento para defender un discurso médico impregnado de evolucionismo, aunque hubiera desarrollos doctrinales desde el ámbito de la jerarquía eclesiástica contrarios claramente a los programas eugenésicos.

Uno de los acercamientos a través de una disciplina que más intensamente ha contribuido a la historiografía sobre el evolucionismo español desde los años ochenta es el representado por la historia de la paleontología. En el ya tantas veces mencionado Congreso de Jaca, el paleontólogo Leandro Sequeiros, autor con el tiempo de una larga serie de trabajos sobre la historia de la paleontología y de la geología, presentó una comunicación en la que centraba su atención en cómo las nuevas ideas científicas habían incidido en la producción de los paleontólogos españoles del siglo XIX; una de las variables consideradas fue, precisamente, el evolucionismo ${ }^{142}$. Además, expuso un segundo trabajo, más centrado en el darwinismo, en el que analizaba la contribución de Juan Vilanova y Piera, científico de la generación intermedia, primer catedrático de la disciplina en España y personaje clave en las polémicas evolucionistas, en las que participó desde posiciones contrarias a las tesis de Darwin pero siempre argumentadas y usualmente centradas en lo científico, al margen de su condición de católico comprometido ${ }^{143}$. En la misma reunión

140 Álvarez Peláez, R. (1985), Las fuentes francesas de la eugenesia de Galton, Asclepio, 37, pp. 165-181; Álvarez PelÁEZ, R. (1985), Sir Francis Galton, padre de la eugenesia, Madrid, CSIC; García González, A., Álvarez Peláez, R. (1999), En busca de la raza perfecta: eugenesia e higiene en Cuba (1898-1958), Madrid, CSIC; GARCía GonZÁleZ, A., Álvarez PelÁEZ, R. (2006), Las trampas del poder: sanidad, eugenesia y migración: Cuba y Estados Unidos (1900-1940), Madrid, CSIC. Además, es la traductora de GALTON, F. (1988), Herencia y eugenesia, Madrid, Alianza.

141 Álvarez Peláez, R. (1988), El Instituto de Medicina Social: primeros intentos de institucionalizar la eugenesia, Asclepio, 40 (1), pp. 343-358.

142 SequeIRos, L. (1984a), Producción científica paleontológica española en el siglo XIX: impacto de la modernidad. En HoRMIGÓN (1984), vol. 2, pp. 453-468.

143 Sequeiros, L. (1984b), Impacto del darwinismo en la paleontología española: Juan Vilanova y Piera (1821-1893). En HORMIGÓN (1984), vol. 1, pp. 523-538. 
científica, Francisco Pelayo presentó un trabajo en cierto modo complementario del anterior, en el que trazaba una marco general de las argumentaciones antidarwinistas en España que se fundamentaban en la paleontología, con mención de Vilanova, pero también de otros autores, y en la que mostraba la conexión de esta línea argumentativa con la tradición concordista que arrancaba de comienzos del siglo XIX, con su intento de defender la perfecta armonía de la verdad religiosa revelada con la verdad de la ciencia natural ${ }^{144}$. Las líneas maestras marcadas por estas dos contribuciones serán desarrolladas en trabajos posteriores, más ambiciosos, tanto por Sequeiros ${ }^{145}$ como, muy especialmente, por Pelayo. Este autor, a partir del análisis de la producción paleontológica, ha desarrollado una eficaz reconstrucción del debate entre ciencia y religión en la España decimonónica ${ }^{146}$. Su enfoque marca una vía en cierto modo en sentido contrario a las aproximaciones de los autores de los años setenta: se trata de encontrar en la obra propiamente científica de los paleontólogos la base de los argumentos que luego se emplearán, por ellos mismos, desde ellos mismos o contra ellos mismos, en la sustanciación de la polémica. La historia desde el presupuesto emanado de la ideología, construida a partir de fuentes esencialmente concebidas para tal polémica, se complementa gracias a la aportación de Pelayo con una historia desde el argumento derivado de la práctica científica. Esto permite, por un lado, valorar eficazmente la incorporación del evolucionismo al quehacer de los paleontólogos; y por el otro, mostrar que los esquemas de recepción y difusión de las ideas evolucionistas en España habían minusvalorado en exceso la dimensión de la propia práctica científica, así como la propia variedad de influencias recibidas ${ }^{147}$.

144 Pelayo, F. (1984), La paleontología. Un argumento para rebatir al darwinismo en el intento de armonizar ciencias naturales y religión. En HORMIGÓN (1984), vol. 1, pp. 475-488.

145 Sequeiros, L. (1988), Desarrollo histórico de la paleontología en España en el siglo XIX. En Historia de la Paleontología, Madrid, Real Academia de Ciencias Exactas, Físicas y Naturales, pp. 31-43. SEQueIRos, L. (1989), La paleontología en España en el siglo XIX, Llull, 12, pp. 151-180.

146 La tesis doctoral de Pelayo, leída en 1988, trata precisamente sobre ciencia y creencia en España durante el siglo XIX; fue dirigida por Joaquín Fernández Pérez, profesor en la Facultad de Biología de la Universidad Complutense de Madrid, cuya labor de tutela doctoral de otros varios historiadores de la biología debe contemplarse, en sí misma, como una contribución capital a la consolidación de la historia de la ciencia en España. Sobre el magisterio de Fernández, v. GoMIS, JosA (2003), pp. 111-115.

147 Son muy numerosos los trabajos de Pelayo en los años ochenta y noventa sobre paleontología, evolucionismo y religión. Entre los principales, v. PELAYO, F. (1988), Ciencia y religión en España durante el siglo XIX, Asclepio, 40 (2), pp. 187-207; PELAYO, F. (1996), Creacionismo y evolucionismo en el siglo XIX: las repercusiones del Darwinismo en la co- 
Otras aproximaciones desde el ámbito de la historia de las disciplinas han tratado también, aunque sólo tangencialmente, las cuestiones relacionadas con la recepción del evolucionismo y su incorporación a la práctica científica. Debemos recordar, desde la historia de la botánica, las contribuciones de Josep Maria Camarasa ${ }^{148}$ y Antonio González Bueno ${ }^{149} \mathrm{y}$, desde luego, los estudios sobre el origen de la ecología en España desarrollados por Santos Casado ${ }^{150}$.

\section{LA MICROESCALA DE LAS INSTITUCIONES, LOS CONTEXTOS LOCALES Y LAS AC- TITUDES PERSONALES}

La complejidad conceptual que envuelve el término evolucionismo ha llevado a que las aproximaciones a gran escala no sean, en ocasiones, lo suficientemente capaces de demarcar las teorías concretas que se adoptaban, desarrollaban o reivindicaban (o alternativamente, se rechazaban, obstaculizaban y debelaban) bajo tan amplio paraguas. A título de ejemplo, podemos hacer mención de la crítica de Sequeiros a Núñez, por decir que Vilanova «insinuó la posibilidad, aunque él no fuera un convencido darwinista, de hacer compatible el transformismo con la religión católica» ${ }^{151}$. Sequeiros apuntaba que «la expresión de Núñez [...] me parece inexacta por cuanto Vilanova, al menos desde 1876 , se manifiesta abiertamente contrario al darwinismo» ${ }^{152}$. El problema de fondo es, ciertamente, la asignación de la etiqueta de «darwinista» a todo aquel autor que dejara un margen de posibilidad al hecho evolutivo. Una crítica que es posible plantear a una parte nada despreciable de la historiogra-

\footnotetext{
munidad científica española, Anales del Seminario de Historia de la Filosofía, 13, pp. 263284; Pelayo, F. (1998), Las polémicas sobre las teorías paleontológicas en la Sociedad Española de Historia Natural, Memorias de la Real Sociedad Española de Historia Natural, (2. ${ }^{\text {a }}$ época), 1, pp. 205-219; PELAYO, F. (1999), El conflicto entre ciencia y creencia en España a finales del siglo XIX. En Puerto, F.J., Alegre, M.E., Rey, M. (coord.), 1898. Sanidad y Ciencia en España y Latinoamérica durante el cambio de siglo, Madrid, Universidad Complutense de Madrid/Doce Calles, pp. 107-119. Todos culminan en PELAYo, F. (1999), Ciencia y creencia en España durante el siglo XIX, Madrid, CSIC.

148 Camarasa, J.M. (1989), Botànica i botànics dels Països Catalans, Barcelona, Enciclopèdia Catalana, pp. 173-174.

149 GonZÁlez Bueno, A. (1997), La botánica en la España de la segunda mitad del siglo XIX, Zubia, 9, pp. 29-44, p. 34.

150 CASADO (1997), passim.

151 NÚÑEZ (1977), p. 40.

152 SEQueIROS (1984b), p. 535.
} 
fía sobre el evolucionismo en España es ésta: ¿cómo asumir que el darwinismo se recibe y difunde en España de manera generalizada entre ciertos sectores sociales, culturales y científicos, y admitir al mismo tiempo que las doctrinas de Haeckel son las que marcan la pauta de tal recepción? Haeckel fue, por utilizar un término de Glick ${ }^{153}$, «apóstol» de Darwin en Alemania, pero no precisamente fiel y estricto en la predicación de la doctrina, que mixturó con las de otros «profetas» y aderezó con desarrollos propios; al final, Haeckel fue un sincretista evolucionista, al par que heresiarca del darwinismo cuya ortodoxia conculcó de múltiples modos. Ciertamente, si atendemos la reflexión de Ernst Mayr ${ }^{154}$ de que en realidad son cinco las teorías de Darwin y, en cierto modo, ya es darwinista quien asume alguna de ellas, podemos recurrir a una consideración más laxa, más «sociológica» si se quiere, de qué supone ser darwinista en las décadas inmediatamente posteriores a la publicación del Origen; pero la dificultad de encontrar adherentes integrales a la totalidad del programa darwinista, como señala, entre otros autores, Peter Bowler ${ }^{155}$, permanece; y el caso español no es, precisamente, una excepción. Ante esto, las aproximaciones desde la escala reducida del caso local o personal, y en su caso también, de la historia institucional, pueden aportar matices de extraordinario valor a la hora de estimar la variedad de recepciones o elaboraciones que conoció el evolucionismo.

Si atendemos a la valoración desde los contextos locales, debemos señalar la existencia de estudios específicos ya, por lo menos, desde los años setenta. Uno de los primeros casos estudiados fue el gallego. José Ramón Barreiro, profesor de historia contemporánea, María Rosaura Rodríguez Díaz y Luz Ruibal tomaron el evolucionismo en la Galicia decimonónica no sólo por su valor en sí, sino también como referente para explicar el fracaso del progresismo científico en Galicia y España. Pese a ciertas ingenuidades, lo temprano del estudio y la ambición de sus planteamientos merecen una consideración detallada. Los autores localizaban unas razones confesas, intelectuales, para explicar el rechazo al evolucionismo: la necesidad de unos esquemas filosóficos distintos a los escolásticos y la exigencia de reinterpretación de la Biblia. Pero buscaban también razones estructurales. Así, argumentaban una fundamentación política para las polémicas evolucionistas en el entendimiento en-

153 GLICK (1985), pp. 438 y ss.

154 MAYR, E. (1988), Toward a new philosophy of biology, Cambridge, Mass./London, Harvard University Press, pp. 196-214.

155 BOWLER, P.J. (1988), The non-Darwinian Revolution: reinterpreting a historical myth, Baltimore, The Johns Hopkins University Press. 
tre los gobiernos moderados y el poder eclesiástico — que garantizaba el poder social y económico de ambas partes-, con un énfasis particular en el control de la enseñanza y, en general, del pensamiento; la respuesta al mantenimiento de la ignorancia del pueblo fomentada por los moderados fue la demagogia de los liberales, condenada al fracaso. A todo ello coadyuvó, en clave intelectual, la esclerotización del discurso teológico: una «malversación del dogma», que llevó a dar categoría dogmática a la escolástica y a generar una «teología cosicista» incapaz de responder a un reto nuevo ${ }^{156}$. El evolucionismo en Galicia ha sido estudiado posteriormente por Xosé Antón Fraga, participante ya en el Congreso de Jaca con una comunicación sobre el asunto en la que, entre otras novedades, apelaba a una prospectiva no sólo en el ámbito universitario, sino también en los institutos de bachillerato para aquilatar la recepción del evolucionismo. Fraga, además, recuperaba como referencia la figura del naturalista Víctor López Seoane, apenas estudiada hasta entonces y de quien constaba su fuerte compromiso evolucionista ${ }^{157}$.

Otro de los primeros casos locales de recepción del evolucionismo en ser tomados como referencia es el valenciano, como atestigua la obra de Glick ${ }^{158}$. También López Piñero se ha ocupado repetidas veces del asunto, tanto en aportaciones de conjunto sobre la historia de las disciplinas médicas y biológicas en Valencia159 como en aproximaciones desde la historia institucional ${ }^{160}$, que han dado un esquema básico condicionado por la recepción en el mundo médico, parcialmente reorientado por otros autores que han incorporado la perspectiva de los naturalistas ${ }^{161}$.

156 BARreiro, J.R., RodríGuez DíAZ, M.R., Ruibal, L. (1971), El evolucionismo en Galicia en el siglo XIX, Compostellanum, 16, pp. 539-574.

${ }^{157}$ Fraga, X.A. (1984), Aportación ao estudo da polémica darvinista na Galiza do século XIX. En HoRMIGÓN (1984), vol. 1, pp. 371-387.

158 Fundamentalmente, GLICK $(1971,1982 b)$.

159 LÓPEZ PiÑERO, J.M. (1988), Las ciencias morfológicas. En Las ciencias médicas básicas en la Valencia del siglo XIX, Valencia, Alfons el Magnànim-IVEI/Institut d'Estudis Juan Gil-Albert, pp. 65-162, especialmente pp. 117-138. También LÓPEZ PIÑERO, J.M. (2004), La medicina y las ciencias biológicas en la historia valenciana, Valencia, Ajuntament de València, pp. 340-378.

160 LóPez PiÑERo, J.M. (2002), La Facultad de Medicina de Valencia (1502-2002). Breve historia de medio milenio, Valencia, Universitat de València, pp. 185 y ss.

161 CATALÁ, J.I. (2001), Camins de controvèrsia: la recepció de l'evolucionisme a València, Mètode, 28, pp. 47-52. La recepción del evolucionismo en Cataluña, Valencia y las Islas Baleares es tratada también en CAMARASA, J.M., CATALÁ, J.I. (2008), Els nostres naturalistes, vol. 2, València, Universitat de València, passim. 
Muy importante fue la aproximación al caso extremeño, a cargo de Fernando Tomás Pérez González, autor de una monografía que, entre otras cuestiones de interés, indagaba en la recepción del evolucionismo en ámbitos urbanos que no eran capitales de provincia, como Plasencia, o en un caso de recepción silenciosa como fue el de Cáceres, frente a la situación más típica de polémica abierta en Badajoz ${ }^{162}$. También han merecido atención las polémicas evolucionistas en Aragón, con el tardío episodio (1909) que protagonizó Manuel Bescós ${ }^{163}$, que muestra hasta qué punto hay que ser prudente en generalizar la visión de que el componente controvertido de la cuestión darwinista estaba superado en el primer tercio del siglo XX. Los casos murciano ${ }^{164}$, cántabro ${ }^{165}$ y malacitano ${ }^{166}$ cuentan también con estudios específicos, mientras que el caso canario - otro clásico - aparece tratado en una obra general sobre la historia de la ciencia en tal ámbito geográfico ${ }^{167}$.

Los enfoques basados en el análisis de la obra de personajes concretos suele permitir una reflexión muy ajustada sobre las tipologías de evolucionismo o antievolucionismo representadas en España; un asunto que, como ya hemos avanzado, resulta comprometido en las aproximaciones a gran escala. Como ha señalado Xosé Antón Fraga ${ }^{168}$, no son pocos los autores que han sido reputados de darwinistas en los que tal consideración difícilmente se sostiene. Por esta razón, la aproximación a la obra personal adquiere un valor muy considerable. Precisamente el análisis de la labor de López Seoane como herpetólogo ha permitido a Fraga estudiar la incorporación efectiva a la práctica naturalista de orientaciones inequívocamente evolucionistas, como demuestra el cam-

162 PÉrez GonzÁlez, F.T. (1987), La introducción del darwinismo en la Extremadura decimonónica, Cáceres, Institución Cultural «El Brocense». Para una aproximación a la obra del erudito extremeño Fernando Tomás Pérez (1953-2005), v. NúÑEZ, D. (2006), In memoriam de Fernándo T. Pérez González, Revista de Hispanismo Filosófico, 11, pp. 95-96.

163 Martínez Tejero, V. (1984), Los intelectuales aragoneses del siglo XIX ante el darwinismo y el evolucionismo en general. En HoRMiGÓN (1984), vol. 1, pp. 457-463.

164 LÓPEZ FernÁNDEZ, C. (1994), El evolucionismo en Murcia (1870-1880) a través de la prensa cultural y científica, Llull, 17, pp. 89-102.

165 Gómez Pellón, E. (1997), Un capítulo de la historia del pensamiento antropológico en España. Darwinismo y ortodoxia en el contexto de la Cantabria decimonónica. En Actas do III Congreso de História da Antropoloxia e Antropoloxia Aplicada, Santiago, Instituto de Estudos Galegos Padre Sarmiento, pp. 61-77.

166 Granda, A. (1998), El darwinismo en Málaga, Málaga, Universidad de Málaga.

167 Martín Del Castillo, J.F. (2003), Ciencia y técnica en las Islas Canarias. Síntesis histórica, La Laguna, Benchomo, pp. 119-127.

168 FragA, X.A. (2002), La recepción del darwinismo por los naturalistas españoles del siglo XIX, un análisis general. En PUIG-SAMPER, RUIZ, GALERA (eds.) (2002), pp. 249-265. 
bio en la taxonomía de los reptiles y anfibios ibéricos que protagonizaron dicho personaje y Eduardo Boscá ${ }^{69}$. Este otro autor, por su parte, ha sido objeto de estudios posteriores, que han revelado las peculiaridades de sus tesis evolucionistas, no perfectamente coherentes además a lo largo de su propia vida científica, primero centrada en la herpetología y posteriormente en la paleontología ${ }^{170}$. En relación con esto, no hay que olvidar que la recepción del evolucionismo corresponde a una época en España de especialización científica todavía incipiente; un énfasis sólo en la historia de las disciplinas puede sesgar la comprensión de ciertos personajes. Los tempranos estudios de Temma Kaplan sobre el médico Luis Simarro Lacabra ya revelaron la importancia de la asunción de las tesis evolucionistas, fundamentalmente a partir de Haeckel, en el desarrollo de su obra científica y de su labor docente, tanto en el ámbito histológico ${ }^{171}$ como en el de la teoría psicológica, campo en el que así mismo recibió influencias spencerianas ${ }^{172}$.

A la postre, han sido numerosas las contribuciones a la historia del evolucionismo español que se han centrado en la obra de individuos. Si atendemos al conjunto de comunicaciones sobre evolucionismo en el Congreso de Jaca, encontramos este tipo de enfoque para filósofos como José Ortega y Gasset ${ }^{173}$ o Miguel de Unamuno ${ }^{174}$, científicos experimentales como Fausto Garagar-

169 V. especialmente Fraga (1989a), así como Fraga, X.A. (1989b), A polémica sobre Triturus boscai LATASTE 1879 na herpetoloxia europea de fins do XIX. A discusión entre dous paradigmas científicos, Asclepio, 41 (2), pp. 281-304. La aportación taxonómica de Boscá, en relación con su asunción del evolucionismo, es específicamente analizada en SÁNCHEZ ARTEAGA, J.M. (2005), Eduardo Boscá Casanoves y la renovación taxonómica de los catálogos faunísticos en España durante el último tercio del siglo XIX, Asclepio, 57 (2), pp. 81-108.

170 CAtalÁ, J.I. (2004), El desarrollo de una carrera científica en un contexto institucional precario: el caso del naturalista Eduardo Boscá Casanoves (1843-1924), Cronos, 7, pp. 3-60; CATAlÁ, J.I. (2005), Eduardo Boscá y el cultivo de la historia natural en la Valencia de la Restauración, Actividades Científicas de la Real Academia de Medicina de la Comunidad Valenciana, 6, pp. 51-72.

171 Kaplan, T. (1971a), Luis Simarro, Spanish histologist. En III Congreso Nacional de Historia de la Medicina. Actas, vol. II, Madrid/Valencia, Sociedad Española de Historia de la Medicina, pp. 523-533.

172 KAPLAN, T. (1971b), Luis Simarro's psychological theories. En III Congreso Nacional de Historia de la Medicina. Actas, vol. II, Madrid/Valencia, Sociedad Española de Historia de la Medicina, pp. 545-555.

173 Ayala, J.M. (1984), Ortega y Gasset (1883-1955) y las ideas evolucionistas. En HORMIGÓN (1984), vol. 1, pp. 319-324.

174 Bernardo, J.M., Serral, P. (1984), Evolucionismo y lingüística en Unamuno. En HORMIGÓN (1984), vol. 1, pp. 325-341. 
$z^{175}$ o José Rodríguez Carracido ${ }^{176}$, y naturalistas como Blas Lázaro Ibiza ${ }^{177}$, Estanislao Vayreda ${ }^{178}$ u Odón de Buen ${ }^{179}$; en conjunto, estos trabajos mostraban cuán complicado era trazar en pocos rasgos las líneas maestras del aspecto doctrinal que envuelve la recepción del evolucionismo. Posteriormente, han venido a añadirse estudios sobre, por ejemplo, Daniel de Cortázar, que han mostrado la penetración de las ideas de Gaudry en España ${ }^{180}$. También sobre Miquel Crusafont ${ }^{181}$, base para una comprensión de la recepción de la nueva síntesis y de la pervivencia de modelos finalistas de evolución y - lo que es aún más significativo- de la imposible laicización del evolucionismo en la España franquista ${ }^{182}$. Y, desde luego, sobre Peregrín Casanova y su estrecha y condicionante relación con Haeckel ${ }^{183}$. La aproximación a la obra del ingeniero de montes Joaquín María de Castellarnau ha permitido matizar mejor la incorporación del evolucionismo a los estudios botánicos ${ }^{184}$. Por su parte, el estudio del ya mencionado José Joaquín Lánderer muestra la complicada situación intelectual de aquellos autores inclinados a una aceptación del

175 MuÑoz Calvo, S. (1984), Contribución de Garagarza y Dugiols al conocimiento del evolucionismo en España. En HoRMIGÓN (1984), vol. 1, pp. 465-471.

176 SÁnchez-Moscoso, A. (1984), Influencias de Darwin en la obra de Rodríguez Carracido [resumen]. En HORMIGÓN (1984), vol. 1, pp. 521.

177 GonzÁlez Bueno, A. (1984), Actitud de Blas Lázaro e Ibiza (1858-1921) ante la corriente evolucionista. En HORMIGÓN (1984), vol. 1, pp. 419-427.

178 VALLÉS, J. (1984), La figura de Estanislau Vayreda i Vila (1848-1901) y su posición frente al darwinismo. En HORMIGÓN (1984), vol. 1, pp. 539-547.

179 ARQUÉs, J. (1984), Els veritables fets sobre la suspensió del científic darwinista Odón de Buen de la seva càtedra de la Universitat de Barcelona el 1895. En HORMIGÓN (1984), vol. 1, pp. 285-303.

180 Sequeiros, L. (1992), Daniel de Cortázar (1844-1927): un evolucionista muy particular. En Paleontología y Sociedad, Madrid/Granada, Sociedad Española de Paleontología/Universidad de Navarra, pp. 173-181.

181 Truyols, J. (1986), L'obra científica del doctor Miquel Crusafont i Pairó (19101983), Butlletí de la Institució Catalana d'Història Natural, 53, pp. 19-36. Agustí, J. (1994), L'evolucionisme meridional de Miquel Crusafont, Arraona, 14, pp. 29-43.

182 GLICK, T.F. (1994), Miquel Crusafont i George Gaylord Simpson: interferències biogràfiques, confluències històriques, Arraona, 14, pp. 45-56.

183 LÓPEZ PIÑERO, J.M. (1989), Peregrín Casanova (1849-1919) y la morfología darwinista, Medicina e Historia, (3. ápoca), 29, pp. 5-28.

184 CASAdo, S., CASAls, V. (1998), La personalidad científica de Joaquín María de Castellarnau. En García Hourcade, J.L., Moreno, J.M., Ruiz Hernández, G. (coord.), Estudios de historia de las técnicas, la arqueología industrial y las ciencias : VI Congreso de la Sociedad Española de Historia de las Ciencias y de las Técnicas, Valladolid, Junta de Castilla y León, pp. 827-837. 
evolucionismo sin que fuera a costa de su profesión de fe católica ${ }^{185}$, mientras que la biografía de Juan Vilanova da la pauta de la opción concordista que siguieron otros autores ${ }^{186}$.

Las contribuciones mencionadas, y otras más que se han quedado en el tintero, se ven incrementadas por el enorme arsenal de datos que proceden de diversos proyectos colectivos de recopilación biográfica. El equipo de redacción del Diccionario Histórico de la Ciencia Moderna en España, publicado precisamente cuando se iniciaba la expansión de los estudios evolucionistas, incluyó varias biografías relacionadas con la cuestión ${ }^{187}$. Igualmente se hizo en el Diccionario histórico das ciencias e das técnicas de Galicia ${ }^{188}$ y en el Diccionario histórico de la antropología española ${ }^{189}$. Y la obra Ciència i tècnica als Països Catalans: una aproximació biogràfica, con un criterio diferente, pues no se trataba de un diccionario biográfico sino de un verdadero repertorio de biografías, incluyó trabajos de referencia sobre autores destacados; para los aspectos aquí tratados, son especialmente relevantes las de Juan Vilanova ${ }^{190}$, José Joaquín Lánderer ${ }^{191}$, Jaime Almera ${ }^{192}$, Odón de Buen ${ }^{193}$, Jaime Pujiula ${ }^{194}$, José Royo ${ }^{195}$ y Miquel

185 Gozalo, R., NAvarro, V. (1996). José Joaquín Lánderer (1841-1922): entre creacionismo y transformismo, Geogaceta, 19, pp. 185-186.

186 Gozalo, R. (1993), Biografía de Juan Vilanova y Piera. En Homenaje a Juan Vilanova y Piera, Valencia, Universitat de València/Diputación de Valencia/Sociedad Económica de Amigos del País de Valencia, pp. 11-83.

187 López Piñero, J.M., Glick, T.F., Navarro, V., Portela, E. (dir.), Diccionario Histórico de la Ciencia Moderna en España, Barcelona, Ediciones 62.

188 Fraga, X.A., Mato, A. (coord.) (1993), Diccionario histórico das ciencias e das técnicas de Galicia. Autores, 1868-1936, Sada-A Coruña, Ediciós do Castro.

189 Ortiz García, C., SÁNChEZ GÓMEZ, L.A. (1994), Diccionario histórico de la antropología española, Madrid, CSIC.

190 Gozalo, R., Salavert, V.L. (1995), Joan Vilanova i Piera (València, 1821-Madrid, 1893). Geòleg, paleontòleg i prehistoriador. En CAMARASA, RoCA (dirs.) (1995), pp. 287-313.

191 Gozalo, R., Navarro, V. (1995), Josep Joaquim Lànderer i Climent (València, 1841-Tortosa, 1922). La recerca fora del món acadèmic: astronomia i geologia. En CAMARASA, RocA (dirs.) (1995), pp. 457-492.

192 Gómez-AlbA, J. (1995), Jaume Almera i Comas (Vilassar de Mar, Maresme, 1845Barcelona, 1919). La geologia apologètica. En CAMARASA, ROCA (dirs.) (1995), pp. 595-621.

193 Bujosa, F., Glick, T.F. (1995), Odón de Buen y del Cos (Zuera, Aragó, 1863-Mèxic, 1945). L'oceanografia. En CAMARASA, RocA (dirs.) (1995), pp. 763-791.

194 Durfort, M. (1995), Jaume Pujiula i Dilmé, S.I (Besalú, Garrotxa, 1869-Barcelona, 1958). La morfologia microscòpica. En CAMARASA, RocA (dirs.) (1995), pp. 827-858.

195 Glick, T.F. (1995), Josep Royo i Gómez (Castelló de la Plana, 1885-Caracas, 1961). La paleontologia a dos continents. En CAMARASA, RocA (dirs.) (1995), pp. 1277-1304. 
Crusafont ${ }^{196}$. Finalmente, es de notar que más de cuarenta entradas en el monumental Dictionnaire du darwinisme et de l'évolution corresponden a biografías de personajes españoles ${ }^{197}$, que acompañan a la descripción del darwinismo autóctono preparada por Diego Núñez ${ }^{198}$.

\section{ENTRE LAMARCK Y LA ACRACIA}

Ya en el estudio de Barreiro, Rodríguez y Ruibal sobre el evolucionismo en Galicia aparecen alusiones a la presencia de las obras de Lamarck en los catálogos de algunas bibliotecas desde comienzos del siglo XIX, así como al conocimiento efectivo de sus ideas durante la primera mitad de ese período ${ }^{199}$. Sin embargo, la mayor parte de estudios sobre la recepción del evolucionismo en España se han realizado desde la perspectiva de intentar localizar la influencia de la obra de Darwin, lo que ha tenido como consecuencia el que las otras versiones del evolucionismo hayan quedado ensombrecidas. Incluso, ha podido fomentar cierta confusión, al hacer pasar por darwinistas aquellas doctrinas que eran simplemente transformistas. En cierta medida, se ha asumido por parte de muchos autores, de una manera más implícita que reflexiva, que el evolucionismo español arranca a partir de las primeras reacciones a la obra de Darwin. Sin embargo, existe evolucionismo no darwinista en España antes y simultáneamente a tales primeras reacciones.

El principal estudioso de la difusión del lamarckismo en España es Agustí Camós, que en una serie de trabajos ha presentado diferentes aspectos de dicha cuestión, localizados sobre todo en Cataluña ${ }^{200}$. Camós ha podido mostrar

196 MAÑOSA (1995).

197 Escritas a su vez por historiadores españoles, como Agustín Albarracín, Alberto Gomis, Antonio González Bueno, Rafael Jerez, Jaume Josa, Diego Núñez, Carlos París, Francisco Pelayo, Fernando T. Pérez, José Luis Peset y Miguel Ángel Puig-Samper.

198 NúÑEZ, D. (1996), Darwinisme espagnol. En TORT, P. (dir.), Dictionnaire du darwinisme et de l'évolution, París, Presses Universitaires de France, pp. 896-900.

199 RODRíGUEZ et al. (1971), pp. 539-540.

200 El conjunto de las investigaciones de Camós sobre el lamarckismo se recoge en su tesis doctoral, junto a otras líneas que ha desarrollado sobre la historia natural en la Real Academia de Ciencias y Artes de Barcelona y la presencia de las ideas de Humboldt en España; v. CAmós, A. (2007), De la història natural a l'evolucionisme. Aspectes de l'estudi de la natura a Catalunya i a Espanya als segles XVIII $i$ XIX, Universitat Autònoma de Barcelona, tesis doctoral por compendio de publicaciones. 
cómo algunos españoles fueron alumnos de Lamarck en París ${ }^{201}$. En cualquier caso, buena parte de su atención se ha centrado en una época posterior, a través de la figura del profesor universitario e impresor Antonio Bergnes de las Casas $^{202}$ y el contenido de la revista La Abeja, que ese mismo personaje impulsó en la década de los sesenta del siglo XIX. La Abeja fue el medio que acogió la traducción de la Histoire Naturelle des Végétaux, la primera obra de Lamarck vertida al castellano, medio siglo antes de que se hiciera lo propio con la Philosphie Zoologique ${ }^{203}$. También acogió diversos artículos anónimos de orientación lamarckista y, a un tiempo, impregnados de las ideas de Etienne Geoffroy Saint-Hilaire ${ }^{204}$. Todo esto hace pensar, obviamente, en una presencia efectiva del lamarckismo en España antes de la recepción de las ideas de Darwin. Las recientes investigaciones de Raimon Sucarrats acerca de la obra y labor docente de Agustín Yáñez en la Barcelona de la primera mitad del siglo XIX han confirmado tal extremo, al mostrar cómo este autor ya se mostraba abiertamente partidario de las tesis de Lamarck en una obra publicada en los años cuarenta de dicho siglo 205 .

La incorporación de ideas lamarckistas, ya en la época posterior a la recepción del darwinismo, se ha revelado fundamental en la articulación del discurso de los anarquistas españoles del cambio de siglo. La relación entre evolucionismo y anarquismo ya aparecía en los trabajos de autores anteriores, especialmente de Núñez, aunque este autor, como ya se ha comentado, se interesó más por el vínculo con el marxismo. De este modo, ha sido Álvaro Girón, investigador actualmente en la Institució Milà i Fontanals del CSIC

201 CAmós, A. (1998), Alumnos españoles en los cursos de Lamarck en el Muséum National d'Histoire Naturelle de París. En García Hourcade, J.L., Moreno, J.M., Ruiz HerNÁNDEZ, G. (coords.), Estudios de historia de las técnicas, la arqueología industrial y las ciencias: VI Congreso de la Sociedad Española de Historia de las Ciencias y de las Técnicas, Valladolid, Junta de Castilla y León, pp. 797-804.

202 CAmós, A. (1998), Antoni Bergnes de las Casas (1801-1879) difusor de la cultura científica y del transformismo lamarckista, Llull, 21, pp. 633-651.

203 CAmós, A. (1995), La traducció de la Histoire Naturelle des Végétaux de Lamarck publicada en la revista La Abeja de Barcelona entre 1862 i 1864. En Puig-Pla, C., CAmós, A., Arrizabalaga, J., Bernat, P. (coord.), Actes de les III Trobades d'Història de la Ciència i de la Tècnica, Barcelona, Societat Catalana d'Història de la Ciència i de la Tècnica, pp. 103-111.

204 CAmós, A. (1997), La difusión de la teoría evolucionista de Lamarck en la revista La Abeja (1862-1870) de Barcelona, Asclepio, 49 (2), pp. 67-84.

205 SUCARRATS, R. (2006), L'ensenyament de la història natural a la Barcelona de la primera meitat del segle XIX. Els llibres de text i la docència d'Agustí Yàñez i Girona, Universitat Autònoma de Barcelona, tesis doctoral, especialmente pp. 137-153 [consulta abierta en http://www.tdx.cat/TDX-1109106-133436 (17-8-2009)]. 
(Barcelona), quien con gran brillantez ha profundizado en el pensamiento libertario español para valorar el impacto del evolucionismo. Los estudios de Girón sobre este asunto se remontan a la redacción de su tesis doctoral ${ }^{206}$, dirigida por Raquel Álvarez ${ }^{207}$. Parte de los resultados se avanzaron en un libro, Evolucionismo y anarquismo en España 1882-1914, tal vez algo inmaduro en su planteamiento y no siempre claro en su articulación, pero muy rico en sugerencias ${ }^{208}$, desarrolladas después en la potente monografía que es $E n$ la mesa con Darwin ${ }^{209}$. Las fuentes de la prensa libertaria son ampliamente explotadas en estos trabajos, que se centran de hecho en la producción de las dos generaciones de autores anarquistas de referencia, en las que dominan alternativamente los trabajadores manuales y los individuos con formación científico-técnica. En todos ellos, afloran peculiares concepciones de la naturaleza, en no pocas ocasiones contradictorias. La animalidad del hombre será, desde luego, asunto central. Y el sentido que se le da a los conceptos darwinistas - muy especialmente, el de la lucha por la existencia, especialmente polémico y con frecuencia impugnado, lógicamente, desde la llamada a la solidaridad-, lo mismo que las teorías de Spencer o de Haeckel, están marcados por mediaciones complejas; destaca la dependencia de las referencias francesas y el escaso eco que encuentran las polémicas autóctonas en los medios anarquistas españoles. La influencia del neolamarckismo en éstos ha sido bien detectada por Girón, en sus estudios sobre la metáfora de la degeneración ${ }^{210}$ y sobre la analogía entre herencia fisiológica y memoria ${ }^{211}$. Muchas de las propuestas de los anarquistas españoles desde los últimos años del siglo XIX estuvieron, a la postre, inspiradas o marcadas por la obra de Piotr Kropotkin, que, como el propio Girón ha mostrado, ensayó una síntesis entre

206 GIRÓN, A. (1996), Evolucionismo y anarquismo: la incorporación del vocabulario y los conceptos del evolucionismo biológico en el anarquismo español, Universidad Complutense de Madrid, tesis doctoral.

207 Álvarez también se ha interesado por la relación entre evolucionismo y anarquismo, desde su interés por la historia de la eugenesia; v. Álvarez PelÁEZ, R. (1995), Eugenesia y darwinismo social en el pensamiento anarquista. En HofmanN, B., JoAn I TOUS, P., TIETZ, M. (ed.), El anarquismo español y sus tradiciones culturales, Francfort/Madrid, Vervuert, pp. 29-40.

208 Girón, A. (1996), Evolucionismo y anarquismo en España 1882-1914, Madrid, CSIC.

209 Girón, A. (2005), En la mesa con Darwin. Evolución y revolución en el movimiento libertario en España (1869-1914), Madrid, CSIC.

210 GIRÓN, A. (1999), Metáforas finiseculares del declive biológico: degeneración y revolución en el anarquismo español, Asclepio, 51 (1), pp. 247-273.

211 GIRÓN, A. (2000), ¿Hacer tabla rasa de la historia?: la analogía entre herencia fisiológica y memoria en el anarquismo español (1870-1914), Asclepio, 52 (2), pp. 99-118. 
Darwin y Lamarck en su intento de construir una ética evolucionista libre de maltusianismo ${ }^{212}$.

\section{LA (DESEABLE) CONSOLIDACIÓN DE UNA EMPRESA COLECTIVA}

Los diversos enfoques en torno a la historia del evolucionismo español que se han venido desarrollando, según hemos relatado aquí, durante las dos últimas décadas del siglo XX, hallaron ocasión de encuentro con ocasión del Coloquio sobre la Recepción del darwinismo en Iberoamérica: un análisis comparativo, que tuvo lugar en Cancún (México) en noviembre de 1997, y que supuso en buena medida la reactualización del enfoque comparativo que, como ya hemos visto, no ha dejado de animar las propuestas de Glick sobre la historia de la difusión y recepción de las grandes teorías científicas contemporáneas ${ }^{213}$. Muchas de las ponencias presentadas, relativas a países americanos, como Argentina, México, Cuba, Uruguay, Bolivia, Brasil y Perú, son muestra del vigor que manifiestan los estudios sobre historia del evolucionismo en tales contextos. Por su parte, las contribuciones españolas probaban la evidencia de cómo la ampliación de tales estudios en nuestro país, constante desde comienzos de los ochenta, y creciente en volumen y perspectivas, ha conformado ya un cuerpo de conocimiento decantado, fruto de la labor de una serie de autores que empezaban precisamente en ese encuentro a hallar un espacio donde consolidar la empresa colectiva de historiar el evolucionismo español. Los resultados del encuentro, además, encontraron una vía privilegiada de difusión en la comunidad internacional, pues la versión española de las contribuciones ${ }^{214}$ acabó estando acompañada de la inglesa, publicada por una editorial de referencia como es Kluwer ${ }^{215}$. La historiografía del evolucio-

212 GIRÓN, A. (2003), Kropotkin between Lamarck and Darwin: the impossible synthesis, Asclepio, 55 (1), pp. 189-213.

213 Glick, T.F., Ruiz, R., Puig-Samper, M.A. (1999), Introducción. En Glick, T.F., Ruiz, R., PUIG-SAMPer, M.A. (eds.), El darwinismo en España e Iberoamérica, Madrid, UNAM/CSIC/Doce Calles, pp. 11-16. V. también GLICK (1993). A comienzos de la década, Glick había realizado otro ensayo comparativo para los casos de la Europa mediterránea y de Latinoamérica; v. GLICK, T.F. (1992), El impacto del darwinismo en la Europa mediterránea y Latinoamérica. En Lafuente, A., Sala, J. (eds.), Ciencia colonial en América, Madrid, Alianza, pp. 319-350.

214 Glick, Ruiz, Puig-SAMPer (eds.) (1999).

215 Glick, T.F., Ruiz, R., Puig-Samper, M.A. (eds.) (2001), Darwinism in the Iberian World, Boston, Kluwer Academic Publishers. 
nismo en España, ya proyectada hacia el reconocimiento internacional por las colaboraciones antes comentadas en el Dictionnaire du darwinisme et de l'évolution, recibió con esta iniciativa un espaldarazo confirmatorio.

Coherentemente con este sentido de consolidación, algunos de los trabajos presentados en este encuentro y recogidos en las publicaciones a que dio lugar tienen su valor principal - sin haber renunciado a la incorporación de novedades - en el sentido de balance de la labor hecha - nunca acabadaen ámbitos ya asentados y maduros de las investigaciones sobre la historia del evolucionismo en España. Son muestra de ello el estudio sobre el darwinismo en la antropología española de Miguel Ángel Puig-Samper ${ }^{216}$, o el dedicado al desarrollo la eugenesia, obra naturalmente de Raquel Álvarez ${ }^{217}$. Otros suponen el intento de superar una situación de carencia, como en el caso de la aportación de Susana Pinar, centrada en la incorporación de conceptos darwinistas en la botánica española del siglo XIX ${ }^{218}$, o la sistematización que Francisco Pelayo realizó del impacto del evolucionismo en la Sociedad Española de Historia Natural219, un asunto sobre el que había noticias aquí y allá pero que adolecía de una exposición coherente ${ }^{220}$. También hubo trabajos relacionados con lo que entonces eran líneas que se estaban abriendo, y que han acabado bien asentadas; fue el caso de la contribución de Girón sobre el concepto de lucha por la existencia entre los anarquistas ${ }^{221}$. E incluso, ejemplos de conexión con ámbitos tan potentes como la historia de la salud

216 Puig-SAMPER, M.A. (1999), El darwinismo en la antropología española. En GLICK, RUIZ, PUIG-SAMPER (eds.) (1999), pp. 153-167.

217 Álvarez Peláez, R. (1999), Características y desarrollo de la eugenesia española. En GLICK, RUIZ, PUIG-SAMPER (eds.) (1999), pp. 215-229.

218 PINAR, S. (1999), Darwinismo y botánica. Aceptación de los conceptos darwinistas en los estudios botánicos del siglo XIX en España. En GLICK, RUIZ, PUIG-SAMPER (eds.) (1999), pp. 133-152.

219 Pelayo, F. (1999), La repercusión del evolucionismo en la Sociedad Española de Historia Natural. En GLICK, RUIZ, PUIG-SAMPER (eds.) (1999), pp. 115-131.

220 Precisamente por aquellas fechas, se estaba trabajando en la elaboración de un volumen colectivo sobre la historia de la Sociedad Española de Historia Natural, y que apareció como primer volumen (monográfico) de las restauradas Memorias de la Real Sociedad Española de Historia. Varios de los artículos allí aparecidos —en los que dominaba la aproximación a partir de la historia disciplinar- hacen patente la discusión de ideas evolucionistas en el seno de la Sociedad; v. BARATAS, L.A., FERNÁNDEZ PÉrEZ, J. (eds.), Aproximación histórica a la Real Sociedad Española de Historia Natural. Memorias de la Real Sociedad Española de Historia Natural, (2. época), 1, pp. 1-258.

221 GIRÓN, A. (1999), La economía moral de la naturaleza: Darwinismo y lucha por la existencia en el anarquismo español (1882-1914). En Glick, Ruiz, Puig-SAMPER (eds.) (1999), pp. 249-263. 
de conexión con ámbitos tan potentes como la historia de la salud pública, de la psiquiatría o de las políticas sanitarias, como el estudio sobre la teoría de la degeneración en España a cargo de Ricardo Campos y Rafael Huertas ${ }^{222}$.

$\mathrm{Al}$ encuentro de Cancún siguió en 2001 una segunda reunión, esta vez en la población extremeña de Jaraíz de la Vera, en la que el enfoque comparado no sólo se mantuvo, sino que se amplió al área de la Europa meridional, con contribuciones francesas, italianas y portuguesas, en lo que era un nuevo paso en la integración internacional ${ }^{223}$. Los estudios centrados en España mostraban el vigor de las nuevas líneas que se iban abriendo. Así, Alberto Gomis y Jaume Josa expusieron los resultados de su paciente búsqueda sobre la iconografía en torno a Darwin y el evolucionismo y su función comunicativa en las polémicas $^{224}$. Francisco Pelayo, por su parte, entraba en el territorio todavía poco explorado de las posturas favorables y contrarias al evolucionismo durante el primer tercio del siglo $\mathrm{XX}^{225}$, mientras Susana Pinar atendía a la respuesta de Jaime Ferrán al mutacionismo 226 . Este enfoque centrado en la obra personal también animaba la aportación de Miguel Ángel Puig-Samper, en torno al médico hispano-cubano Enrique Lluria, personaje controvertido en cuanto a su adscripción ideológica ${ }^{227}$. Los aspectos médico-sociales del evolucionismo eran explorados por Raquel Álvarez ${ }^{228}$. Un rasgo común de estos trabajos es su focalización en el siglo $\mathrm{XX}$, en lo que es un cambio de tendencia muy reseñable $\mathrm{y}$ que, como veremos, se ha consolidado. En cualquier caso, quedaban todavía

222 CAmpos, R., Huertas, R. (1999), La teoría de la degeneración en España (18861920). En GLICK, RuIZ, PUIG-SAMPER (eds.) (1999), pp. 231-248.

223 De este modo, participaron autores tan conocidos como Antonello La Vergata, Goulven Laurent, Carlos Almaça, etc. V. PUIG-SAMPER, RUIZ, GALERA (eds.) (2002).

224 Gomis, A., JosA, J. (2002a), Iconografía darwiniana en España. En Puig-SAMPER, Ruiz, Galera (eds.) (2002), pp. 151-173. Sobre el mismo tema, v. Gomis, A., JosA, J. (2002b), Imágenes de la polémica darwinista en España, Mundo Cientifico, 233, pp. 20-29.

225 Pelayo, F. (2002), Darwinismo y Antidarwinismo en España (1900-1939): La extensión y crítica de las ideas evolucionistas. En Puig-SAMPER, RuIZ, GALERA (eds.) (2002), pp. 267-283. Este autor está abordando con creciente dedicación ese período; v. PELAYO, F. (2007), La evolución humana y su difusión en España en el marco de la JAE (1907-1939), Asclepio, 59 (2), pp. 137-162.

226 PINAR, S. (2002), El bacteriólogo Jaume Ferrán y las mutaciones de Hugo de Vries. En Puig-SAMPER, RUIZ, GALERA (eds.) (2002), pp. 333-352.

227 Puig-SAMPer, M.A. (2002), El pensamiento evolucionistas de Enrique Lluria. En Puig-SAMPER, Ruiz, GALERA (eds.) (2002), pp. 397-407.

228 Álvarez Peláez, R. (2002), El pensamiento evolucionista y su influencia en las ideas médico-sociales durante el primer tercio del siglo XX en España. En PUIG-SAMPER, RUIZ, GALERA (eds.) (2002), pp. 285-306. 
temas que encarar para el siglo XIX, sobre todo en la comprensión de detalle de muchos casos; en esta línea se situaban el estudio sobre Alejandro Oliván a cargo de J. Luis Maldonado ${ }^{22}$ y una nueva aproximación a las polémicas darwinistas en Extremadura, a cargo del malogrado Fernando Tomás Pérez ${ }^{230}$. La coexistencia de niveles de análisis diferentes, afortunadamente, persiste.

El volumen también incluye una pertinente revisión a cargo de Xosé Antón Fraga acerca de la incorporación del evolucionismo en la práctica de los naturalistas españoles: la vieja cuestión no resuelta por Sala y que tan confusa resulta todavía, por la dificultad de localizar adecuadamente en qué punto se da o no tal incorporación, y subsidiariamente, por la de discriminar las tipologías evolucionistas concretas más allá de las adscripciones genéricas y por debajo de los barnices ideológicos ${ }^{231}$.

Algunas contribuciones de autores españoles se ocupaban de asuntos generales o de situaciones allende las fronteras españolas, aunque pudieran relacionarse más o menos con lo que aquí viniera a suceder: las reflexiones de Andrés Galera sobre la relación entre creacionismo y evolucionismo antes y hasta Darwin $^{232}$, el análisis de Rafael Huertas de un caso de presencia novelística del darwinismo (incluido el social) ${ }^{233}$, la aproximación de Álvaro Girón a la difícil integración entre evolucionismo y ética en Kropotkin ${ }^{234}$, o el reencuentro de José Luis Peset con Lombroso ${ }^{235}$. Esta creciente apertura de los historiadores españoles del evolucionismo a temas de alcance más general se ha decantado en los últimos años muy señaladamente, como prueba el monográfico «Historias de la evolución», aparecido en la revista Asclepio en $2000^{236}$. Esta revista, por otro lado, se está consolidando en los últimos años

229 MALDONADO, J.L. (2002), El escritor y político liberal Alejandro Oliván y su crítica al darwinismo. En PUIG-SAMPER, RUIZ, GALERA (eds.) (2002), pp. 125-149.

230 PÉRez GonzÁlez, F.T. (2002), Darwin y los canónigos de Badajoz. En PuiG-SAMPer, RUIZ, GALERA (eds.) (2002), pp. 307-318.

231 Fraga (2002).

232 Galera, A. (2002), Creating evolution. En Puig-Samper, Ruiz, Galera (eds.) (2002), pp. 13-20.

233 Huertas, R. (2002), Darwinismo y Darwinismo social en la obra de E. Zola. En PuIGSAMPER, RUIZ, GALERA (eds.) (2002), pp. 117-124.

234 Girón, A. (2002), Evolucionismo y ética: Pedro Kropotkin. En Puig-SAMPER, RuIZ, GALERA (eds.) (2002), pp. 231-248.

235 Peset, J.L. (2002), La familia Lombroso y el evolucionismo. En Puig-SAMPER, RuIz, GALERA (eds.) (2002), pp. 175-181. Un cuarto de siglo antes, Peset y su hermano Mariano habían publicado un libro sobre Cesare Lombroso; v. PeSET, J.L., PeSET, M. (1975), Cesare Lombroso y la escuela positivista italiana, Madrid, CSIC.

236 GalerA, A. (coord.) (2000), Historias de la evolución [monográfico], Asclepio, 52 (2), pp. 1-282. 
Esta revista, por otro lado, se está consolidando en los últimos años como medio para la publicación de artículos por parte de historiadores europeos del evolucionismo ${ }^{237}$. Una prueba más de la relevancia adquirida por esta parcela de la historia de la ciencia en nuestro país.

¿Qué retos se le abren a la historia del evolucionismo en España? En estos momentos, uno de los aspectos menos considerados hasta la fecha, que es el estudio de lo acontecido en el siglo XX, antes y después de la Guerra Civil, está interesando a varios autores. De algunas líneas al respecto se acaba de hablar. Debemos añadir en este punto la contribución de Francisco Blázquez Paniagua sobre la síntesis neodarwinista en España, tema de la tesis doctoral de este investigador ${ }^{238}$, que también ha publicado contribuciones originales sobre el período anterior a la Guerra Civil239.

Del evolucionismo en el período franquista se ha ocupado asimismo Agustí Camós, a partir de su estudio sobre la figura de José Fuset ${ }^{240}$, mientras que Carlos Acosta ha abierto un sugerente y original campo de análisis con la exploración de una polémica - con censura incluida - sobre el tratamiento de la teoría evolutiva en Televisión Española en fecha tan avanzada como $1971^{241}$. El interés por épocas recientes, en cualquier caso, no ha impedido que se profundice en aspectos relativos al más estudiado tercio final del siglo XIX. De este modo, el siempre versátil Fraga aporta una visión sobre la recepción del darwinismo desde la morfología biológica ${ }^{242}$, mientras que Julio Simó reelabora algunas interpretaciones desde el punto de vista de las ideolo-

237 En el monográfico antes citado colaboraron Goulven Laurent, Carlos Almaça, Giuliano Barsanti i Patrick Tort, quien posteriormente ha publicado en la misma revista; v. TORT, P. (2004), Darwin, eslabón perdido y encontrado del materialismo de Marx, Asclepio, 56 (1), pp. 209-217.

238 BLÁZQUEZ, F. (2004), El evolucionismo en España y la síntesis neodarwinista (19391970), Madrid, Universidad Autónoma de Madrid [recurso electrónico]. V. también BLÁzQUEZ, F. (2001), La teoría sintética de la evolución en España. Primeros encuentros y desencuentros, Llull, 24, pp. 289-313.

239 BlÁzQuEZ, F. (2007), Notas sobre el debate evolucionista en España (1900-1936), Revista de Hispanismo Filosófico, 12, pp. 23-44.

240 CAMós, A. (2006), Josep Fuset Tubià (1871-1952), defensor de l'evolucionisme als anys més negres de la postguerra. En Batlló, J., Ferran, J., PiQueras, M. (coords.), Actes de la VIII Trobada d'Història de la Ciència i de la Tècnica, Barcelona, Societat Catalana d'Història de la Ciència i de la Técnica, pp. 509-515.

241 Acosta, C. (2008), La teoría de la evolución y la censura en TVE. Entre el fijismo, el finalismo ¿y el neodarwinismo?, Actes d'Història de la Ciència i de la Tècnica, 1 (1), pp. 271-277.

242 FraGA, X.A. (2004), Influencias ideológicas en la recepción del darwinismo en morfología biológica a finales del siglo XIX: los casos de los médicos Francisco Romero Blanco y Juan Barcia Caballero, Llull, 27, pp. 401-422. 
gías, especialmente el republicanismo y el krausismo ${ }^{243}$, y Jerónimo Bouza, en su libro sobre la historia de la antropología catalana, amplía el estudio de las polémicas evolucionistas en torno a la condición humana ${ }^{244}$.

Hay que destacar también, entre las más recientes aportaciones, una que por su valor instrumental, a la que une una cuidada edición, es ya una herramienta de trabajo imprescindible: la Bibliografia crítica ilustrada de las obras de Darwin en España (1857-2005), preparada por Alberto Gomis y Jaume Josa ${ }^{245}$. Además de recoger exhaustivamente las ediciones españolas de las obras de Darwin en diversas lenguas, su localización y sus características técnicas, ofrece información útil sobre los prologuistas, comentadores, ilustradores, traductores, editores y demás personajes implicados en tales ediciones, lo cual puede ofrecer un riquísimo material de partida para estudiar el evolucionismo en España desde perspectivas sociales hasta ahora descuidadas. Los estudios de los propios Gomis y Josa sobre iconografía evolucionista, antes comentados ${ }^{246}$, sugieren la posibilidad de aproximaciones desde el estudio de la cultura popular, que algunos hemos tanteado a partir de la explotación de fuentes inhabituales ${ }^{247}$.

Empieza a ser también momento de avanzar en los debates metodológicos. Ya hace años que el modelo difusionista en historia de la ciencia, como otras opciones teóricas fuertemente jerárquicas, viene recibiendo críticas ${ }^{248}$. Esto es

243 Simó, J. (1999), Ciencia, ideología y conflicto político. La polémica evolucionista en España a través del diario republicano La Justicia (1888-1897), Cuadernos de Historia Contemporánea, 21, pp. 213-225; SiMÓ, J. (2004), La Naturphilosophie en España. La recepción del evolucionismo en el entorno de la tradición krausista, Asclepio, 56 (2), pp. 197-222.

244 BouzA, J. (2002), El hombre como problema. Filosofía, ciencia y subversión en la antropología del siglo XIX, Barcelona, El Serbal, pp. 177-187.

245 GOMIS, JOSA (2007).

246 GoMis, JosA (2002a); GOMIS, JosA (2002b).

247 CATAlÁ, J.I. (2003a), La visió popular de la ciència i la tècnica a les falles de València: a la recerca de noves fonts, Revista d'Estudis Fallers, 8, pp. 22-35; CATALÁ, J.I. (2003b), La festa de les falles de València com a font per a l'estudi històric i social de la ciència: una proposta de treball. En BAtlló, J., Bernat, P., Puig, R. (coords.), Actes de la VII Trobada d'Història de la Ciència i de la Tècnica, Barcelona, Societat Catalana d'Història de la Ciència i de la Técnica, pp. 319-327. Una perspectiva teórica en GLICK, T.F., Henderson, M.G. (1999), Las recepciones científicas y populares de Darwin, Freud y Einstein: hacia una historia analítica de la difusión de las ideas científicas. En Glick, Ruiz, Puig-Samper (eds.) (1999), pp. 289-297.

248 SAlavert, V.L. (2005), La història de la ciència i de la tècnica als Països Catalans en els darrers vint-i-cinc anys, Afers, 20 (50), pp. 127-151; v. especialmente p. 144. Una contribución reciente que opone al habitual recurso a los conceptos de difusión, transmisión, in- 
importante para la propia tradición de estudios de que nos hemos ocupado, pues ciertamente ha estado marcada por el hecho de que se asumiera tal modelo en algunas de las contribuciones fundadoras. $\mathrm{Y}$ se han hecho sentir, en cualquier caso, algunas críticas, hechas desde perspectivas que van desde el combate al eurocentrismo hasta el antidesarrollismo, y que en otro orden de problemas, se han combinado con reflexiones sobre los problemas de demarcación y definición de lo que es el darwinismo en el conjunto de las corrientes evolucionistas $^{249}$. También es cierto, sin embargo, que la perspectiva comparada de la que se benefició en su día la historia del evolucionismo español matizó de inicio algunos de los problemas típicos de la perspectiva difusionista, aunque abriera otros en cuanto a las propias condiciones para acometer tal perspectiva ${ }^{250}$.

Nos permitimos, por último, plantear una cuestión final. Visto que el colectivo de especialistas manifiesta cierto vigor -al menos, es nuestra impresión-, ¿es posible a día de hoy plantear una síntesis de la historia del evolucionismo en España? Ya hace años que la dificultad a la hora de ofrecer obras sintéticas acucia a los historiadores de la ciencia ${ }^{251}$. La crisis de la historia tradicional de las disciplinas ha comprometido la permanencia de un dominio en el que la gran síntesis fue norma durante bastante tiempo. Las dificultades para decantar una síntesis comprensiva y articulada del evolucionismo español principian, claro está, con las lagunas que todavía faltan por cubrir. Pero esto es contingente si se mantiene la continuidad de las líneas de trabajo. La ausencia de una opción programática clara plantea, por el contrario, mayores dificultades. La diversidad de enfoques coexistentes que aquí hemos intentado valorar y que hemos juzgado como extraordinariamente enriquecedora, ha podido tener sin embargo un efecto de dispersión que lleva a pensar que, a pesar del sentido colectivo que se ha podido ir madurando, todavía estamos lejos de poder ofrecer un nuevo marco general para el problema. Convendría, a nuestro modesto juicio, avanzar a la vez en los estudios de caso que vayan

fluencia, adopción, etc. (nosotros añadiríamos el de «impacto») el uso del concepto de «apropiación», en GAVROGLU, K. et al. (2008), Science and technology in the European periphery: some historiographical reflections, History of Science, 46, pp. 153-175. El valor de estas propuestas, en todo caso, habrá que calibrarlo a partir de su aplicación a los casos.

249 RESTREPO (2002).

250 Para los pros y contras del enfoque comparado, v. Pyenson, L. (2002), Comparative history of science, History of Science, 40, pp. 1-33.

251 Aunque centrada en el caso catalán, hay reflexiones de utilidad general en RocA, A. (1993), El repte de la síntesi. Antecedents i situació actual de la historiografia catalana de la ciència i de la tècnica, El Contemporani, 1, pp. 35-39. 
planteándose y en la definición de un programa colectivo que pueda rendir, más pronto o más tarde, una síntesis suficiente que sitúe tantas y tantas contribuciones en un panorama común.

\section{AGRADECIMIENTOS}

A Francisco Pelayo, Miguel Ángel Catalá Llorens y Javier Catalá Lliso, así como al Servicio de Obtención de Documentos de la Universidad CEU Cardenal Herrera, por su ayuda en la localización, búsqueda y consulta de algunas de las obras estudiadas.

Fecha de recepción: 14 de diciembre de 2008

Fecha de aceptación: 15 de julio de 2009 